Article

\title{
Effect of Various Peening Methods on the Fatigue Properties of Titanium Alloy Ti6A14V Manufactured by Direct Metal Laser Sintering and Electron Beam Melting
}

\author{
Hitoshi Soyama ${ }^{1, *(\mathbb{D})}$ and Fumio Takeo ${ }^{2}$ \\ 1 Department of Finemechanics, Tohoku University, Sendai 980-8579, Japan \\ 2 Department of Industrial Systems Engineering, National Institute of Technology, Hachinohe College, \\ 16-1 Uwanotai, Tamonoki, Hachinohe 039-1192, Japan; takeo-m@hachinohe-ct.ac.jp \\ * Correspondence: soyama@mm.mech.tohoku.ac.jp; Tel.: +81-22-795-6891; Fax: +81-22-795-3758
}

Received: 26 April 2020; Accepted: 11 May 2020; Published: 12 May 2020

\begin{abstract}
Titanium alloy Ti6Al4V manufactured by additive manufacturing (AM) is an attractive material, but the fatigue strength of AM Ti6Al4V is remarkably weak. Thus, post-processing is very important. Shot peening can improve the fatigue strength of metallic materials, and novel peening methods, such as cavitation peening and laser peening, have been developed. In the present paper, to demonstrate an improvement of the fatigue strength of AM Ti6Al4V, Ti6Al4V manufactured by direct metal laser sintering (DMLS) and electron beam melting (EBM) was treated by cavitation peening, laser peening, and shot peening, then tested by a plane bending fatigue test. To clarify the mechanism of the improvement of the fatigue strength of AM Ti6Al4V, the surface roughness, residual stress, and surface hardness were measured, and the surfaces with and without peening were also observed using a scanning electron microscope. It was revealed that the fatigue strength at $N=10^{7}$ of Ti6Al4V manufactured by DMLS was slightly better than that of Ti6Al4V manufactured by EBM, and the fatigue strength of both the DMLS and EBM specimens was improved by about two times through cavitation peening, compared with the as-built ones. An experimental formula to estimate fatigue strength from the mechanical properties of a surface was proposed.
\end{abstract}

Keywords: additive manufacturing; post-processing; fatigue; Ti6Al4V; cavitation peening; laser peening; shot peening; direct metal laser sintering; electron beam melting

\section{Introduction}

Additive manufactured (AM) titanium alloy is an attractive material for medical implants [1-4] and aviation components [5-7], as the geometry of the parts are directly produced from computer-aided design (CAD) data, and the lead time for production can be reduced remarkably. However, the fatigue strength of AM titanium alloy is significantly weaker, compared to that of wrought materials [5,6,8-11]. As manufacturing conditions and post-processing affect fatigue properties $[5,6,12]$, and mechanical surface treatment improves fatigue strength [5,13-15], it is worthwhile to develop peening methods to improve the fatigue strength of AM titanium alloy.

As is well known, in AM metallic materials, tensile and compressive residual stress are introduced during the AM process $[6,16]$ as a heat source is deposited locally on the material surface; this produces a three-dimensional distribution of temperature in the AM process which is similar to welding $[17,18]$. Moreover, residual stress affects fatigue performance $[19,20]$. Thus, the relaxation of residual stress improves the fatigue life and fatigue strength of AM titanium [21]. A heat treatment after the AM process is one way to improve fatigue properties [21,22]. As defects and pores are also produced in 
AM metallic materials, hot isostatic pressing (HIP) can improve the fatigue properties of AM titanium alloy [22-28]. The surface roughness caused by un-melted particles is one of the reasons for the weak fatigue performance $[29,30]$. However, HIP cannot improve fatigue performance, which is closely affected by surface defects, and it is difficult to apply the HIP process with large-scale components. It was reported that, in the case of AM titanium with an as-built surface, the fatigue life depended on the crack initiation from the rough surface, compared with internal defects [31]. The combined treatment of HIP and chemical etching was reported to improve fatigue properties [32]. There have been a lot of reports that revealed an improvement of fatigue properties by mechanical finishing or polishing after HIP $[8,10,11,21,24,25,27,31,33-36]$. However, some shapes cannot be machined, and the benefits of the topology optimization of AM metals [5,37] are lost.

As mentioned above, a large surface roughness was introduced by the AM process [29,30], cracks were initiated on the as-built surface of AM Ti6Al4V, compared with the machined surface [38], and the relation between the surface roughness and fatigue life of AM Ti6Al4V was reported [39]. Regarding the effect of surface roughness on AM Ti6Al4V, the Kitagawa-Takahashi plot [40], El Haddad-Topper approach [41], and root area parameter [42] have been investigated [43,44]. It was also reported that the fatigue life of AM Ti6Al4V was estimated by the equivalent initial flaw size (EIFS) [45]. In order to reduce the surface roughness, without machining, to improve the fatigue properties of AM Ti6Al4V, surface finishing, such as tribofinishing [46], vibratory finishing [47], electropolishing [48], tumbling [49], barrel polishing [50], chemically accelerated vibratory finishing [51], and cavitation abrasive finishing [15,52] have been proposed. Laser polishing of AM Ti6Al4V was also proposed [53,54]; however, the effect of laser polishing on fatigue properties was not investigated. As is well known, large surface irregularities, such as in as-built AM metals, can be smoothed, as shot peening can deform metallic surfaces. It was reported that the fatigue strength of AM Ti6Al4V at $10^{7}$ cycles was in the order of shot peening, HIP, tribofinishing, electropolishing, and as-built surfaces [46]. Thus, peening methods are some of most effective tools for improving the fatigue properties of AM Ti6Al4V.

While there are several methods for AM Ti6Al4V, the two major methods are direct metal laser sintering (DMLS) and electron beam melting (EBM). In both cases, the environment, temperature, and material particles during the AM process are different. When the fatigue strength of the DMLS and EBM specimens was compared, it was also found that the DMLS specimen had a low roughness and high fatigue strength [31,34,55-61], and the DMLS and EBM specimens were similar [21]. It was also reported that DMLS and EBM specimens have different metallographic structures [61], and the mechanical behavior of tension and compression of AM Ti6Al4V varies, depending on the strain rate [62]. Rozumek and Hepner reported the influence of oxygenation time and heat treatment on fatigue crack propagation under bending in alloy Ti6Al4V [63,64]. Therefore, the fatigue strength of AM Ti6Al4V may differ, depending on the peening method and AM process, just as the strain rate during peening is dependent on the peening method.

In previous studies, the effects of the mechanical surface treatment of AM metals were reported using shot peening $[5,6,13,65-67]$, ultrasonic peening [35,68], laser peening [13,66], and cavitation peening $[13,65]$. It should be noted that shock waves are used in submerged laser peening, as laser ablation and the collapse of the cavitation bubble, which is generated after laser ablation, producing shock waves [69-71]. In the case of cavitation peening, the impact induced by a micro jet and/or shock wave at the cavitation bubble collapse [72] is used for the mechanical surface treatment of metallic materials $[70,73]$. As shots are not used in cavitation peening, there is no material transfer due to shot collisions. This is a great advantage of cavitation peening for the mechanical surface treatment of medical implant applications. The impacts induced by cavitation peening and submerged laser peening might reach the bottom of deep valleys, which are produced by the AM process, and the impacts might enhance the fatigue properties of AM Ti6Al4V with a rough surface, such as as-built surfaces. Regarding the experimental investigation of plastic deformation induced by various peening methods [74], the ratio of the plastic deformation depth and the depth of the dent depend on the peening method. It was also reported that mechanical properties, such as roughness, residual stress, 
hardness, and crack propagation, differ remarkably, depending on the peening method, such as shot peening, laser peening, and cavitation peening [75-77]. As is well known, a peening method changes the surface characteristics, such as roughness, hardness, residual stress, and dislocation density, etc., of metallic materials, and the effect of peening also depends on the materials. Thus, a systematic and experimental investigation should be required to establish a suitable peening method to enhance the fatigue properties of AM Ti6Al4V.

In the present paper, to find out the effects on the fatigue properties of AM Ti6Al4V treated by various peening methods, Ti6Al4V manufactured by DMLS and EBM was treated by cavitation peening, laser peening, and shot peening, and the fatigue performance was evaluated by a plane bending fatigue test, comparing it with that of as-built specimens. In order to investigate the peening effects on the surface characteristics of Ti6Al4V manufactured by DMLS and EBM, the surface roughness, hardness, and residuals stress of the surface, with and without peening, were measured, and the surface was observed by a scanning electron microscope and a laser confocal microscope. An experimental formula to estimate the fatigue strength from the surface roughness, surface hardness, and residual stress was proposed, and it was verified.

\section{Materials and Methods}

\subsection{Titanium Alloy Manufactured by DMLS and EBM}

Figure 1 shows the shape of the specimens for a displacement-controlled plane bending fatigue tester. The specimens were manufactured by DMLS and EBM. The thickness of the specimen manufactured by DMLS was $2.6 \pm 0.2 \mathrm{~mm}$, considering the result of a previous report [13], due to the limitations of the displacement and the maximum moment of the tester. In the case of EBM, the thickness was $2 \pm 0.2 \mathrm{~mm}$, which was also found in a previous report [13]. The stacking direction of both DMLS and EBM specimens was in the width direction. After the DMLS and EBM process and then the heat treatment, the edges of all the specimens were rounded by hand using rubber whetstones of \#80 and \#180 to reduce the crack initiation from the edges; this was also conducted in a previous report [13]. To investigate mechanical polishing, the surface of the specimens manufactured by DMLS was grinded by rubber whetstones of \#80 and \#180, and it marked as "grinding" in the present paper.

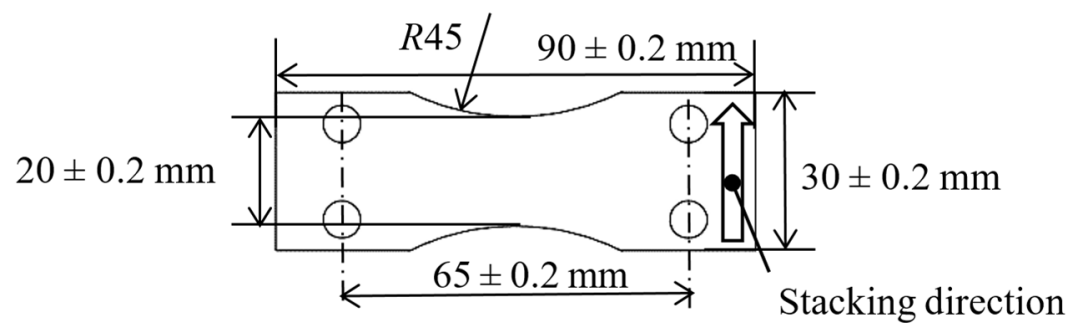

Figure 1. Geometry of the fatigue specimen for the displacement-controlled plane bending fatigue test. The thickness was $2.6 \pm 0.2 \mathrm{~mm}$ for the direct metal laser sintering (DMLS) specimen and $2.0 \pm 0.2 \mathrm{~mm}$ for the electron beam melting (EBM) specimen.

The particle used in the DMLS process was made of Ti6Al4V, and its average diameter was about $40 \mu \mathrm{m}$. The power, beam diameter, and scanning speed of the laser of DMLS was $400 \mathrm{~W}, 200 \mu \mathrm{m}$, and $7 \mathrm{~m} / \mathrm{s}$, respectively. The stacking pitch was $60 \mu \mathrm{m}$. After the DMLS process, the specimen was annealed at $923 \mathrm{~K}$ for $3 \mathrm{~h}$ to reduce the residual stress in the specimen. After the annealing, the solution heat treatment was conducted at $1208 \mathrm{~K}$ under vacuum conditions for $105 \mathrm{~min}$, then cooled in argon. After that, aging was conducted at $978 \mathrm{~K}$ under vacuum conditions for $2 \mathrm{~h}$, followed by argon gas cooling.

The particle used in the EBM process was made of Ti6Al4V, and its average diameter was about $75 \mu \mathrm{m}$. The spot size of the electron beam for selective melting was $0.2 \mathrm{~mm}$ in diameter, and the 
stacking pitch was $90 \mu \mathrm{m}$, which was the same in a previous report [13]. After the EBM process, the solution heat treatment and aging were conducted in the same way as the DMLS specimens.

\subsection{Cavitation Peening}

Figure 2 shows a schematic diagram of the peening section of the cavitation peening system. In the present experiment, a submerged high-speed water jet was used to generate cavitation. The high-speed water jet was pressurized by a plunger pump, with a maximum working pressure of $30 \mathrm{MPa}$ and maximum flow rate of $3 \times 10^{-2} \mathrm{~m}^{3} / \mathrm{min}$ and injected into a chamber filled with water. The injection pressure was controlled by the rotational speed of the invertor motor of the plunger pump. When the high-speed water jet was injected into the chamber, cloud cavitation was generated inside the nozzle and/or in the shear layer around the jet. A submerged jet with a cavitation bubble is called a cavitating jet [70]. On the impinging surface, cloud cavitation became a ring vortex cavitation, then collapsed. Thus, the area treated by the fixed cavitating jet shows an annular shape [70], and the scanning cavitating jet can treat the surface uniformly [78]. In the present paper, the specimen, which was put in a recess to make a flat surface, was placed perpendicular to the jet in the chamber. The specimen was treated by scanning the nozzle, which moved horizontally at a constant speed $v$. The throat diameter of the nozzle was $2 \mathrm{~mm}$. As the cavitator and the guide pipe can enhance the aggressive intensity of the cavitating jet [79], both of them were installed in the nozzle. The diameter of the cavitator was $3 \mathrm{~mm}$, which was optimized in a previous study [79]. As the geometry of the outlet bore at the nozzle affects the aggressive intensity of the cavitating jet, the length $L$ and the diameter $D$ of the bore were optimized as $L=16 \mathrm{~mm}$ and $D=16 \mathrm{~mm}$ [80]. As the cavitating flow was separated at the upstream corner of the nozzle, the standoff distance $s$ was defined by the distance from the upstream corner of the nozzle to the surface of the specimen. When the specimen is set too close to the nozzle, even though there is the cavitating jet, the specimen is treated by water jet peening, in which water columns peen the target. The classification map, in which cavitation peening and water jet peening were classified using the normalized standoff distance and cavitation number, was proposed [73]. The standoff distance chosen in the present experiment was $s=222 \mathrm{~mm}$, which was the same in a previous report [13], and this was the cavitation peening condition.

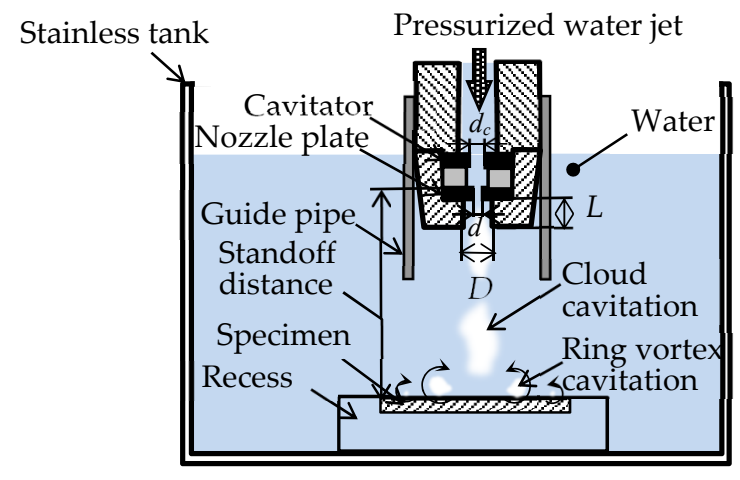

Figure 2. Schematic diagram of the peening section of the cavitation peening system.

The processing time per unit length $t_{p}$ is defined as follows.

$$
t_{p}=\frac{n}{v}
$$

where $n$ is the number of passes. In the present experiment, the processing time per unit length $t_{p}=10$ $\mathrm{s} / \mathrm{mm}$, which was the same in a previous study [13], was used to compare the cavitation peening effect on Ti6Al4V manufactured by DMLS and EBM. 


\subsection{Laser Peening}

Figure 3 shows a schematic diagram of the peening section of the laser peening system. In the present experiment, a submerged laser peening system was used. In most cases, in conventional submerged laser peening, the second harmonic of the Nd:YAG laser (i.e., $532 \mathrm{~nm}$ in wave length), is used to mitigate the absorption of laser power due to water. As mentioned in the introduction, the impact at the collapse of the bubble, which is developed and collapses after laser ablation, is also affective for peening. In experimental studies of bubble dynamics, the fundamental harmonic of the $\mathrm{Nd}$ :YAG laser (i.e., $1064 \mathrm{~nm}$ ) is used to harness the heat [81]. Soyama revealed that submerged laser peening, using a laser of $1064 \mathrm{~nm}$ in wave length, introduced compressive residual stress when the distances in air and water were optimized [82]. Thus, in this experiment, the wavelength of $1064 \mathrm{~nm}$ was used, which was the same in a previous report [13]. The pulse energy, beam diameter, pulse width, and repetition frequency of the used Q-switched Nd:YAG laser were $0.35 \mathrm{~J}, 6 \mathrm{~mm}, 6 \mathrm{~ns}$, and $10 \mathrm{~Hz}$, respectively. To minimize the damage to a glass chamber due to the laser, the laser was reflected by mirrors and expanded by a concave lens, then focused by convex lenses onto the specimen placed in the water-filled chamber, whose thickness was $3 \mathrm{~mm}$. The length, width, and depth of the chamber were each $150 \mathrm{~mm}$. The deionized water was fed into the chamber at about $5 \times 10^{-3} \mathrm{~m}^{3} / \mathrm{min}$ to remove particles caused by the ablation. It should be noted that the water was degassed to minimize the cushion effect at the bubble collapse. The focal distance of the final convex lens was $100 \mathrm{~mm}$. In order to minimize damage to the mirrors and lenses due to the reflection between the final convex lens and the chamber, the convex was placed as shown in Figure 3. In the present laser peening, the distances in air $s_{a}$ and in water $s_{w}$ were $84 \mathrm{~mm}$ and $19 \mathrm{~mm}$, respectively, which was the same in a previous study [13]. In the present condition, the diameter of the laser spot on the specimen surface was about $0.8 \mathrm{~mm}$. The specimen was placed on a stage, which was moved by linear stepping motors in the vertical and horizontal directions. The pulse density $d_{L}$ was controlled by the horizontal speed $v_{S}$ and the stepwise movement in the vertical direction $s_{v}$ using the stepping motors. As the repetition frequency was $10 \mathrm{~Hz}, d_{L}$ was defined by Equation (2).

$$
d_{L}=\frac{10 n}{v_{h} s_{v}}
$$

In the present experiment, $d_{L}$ was set to 5 pulses $/ \mathrm{mm}^{2}$, with $n=1, v_{h}=4.46 \mathrm{~mm} / \mathrm{s}$, and $s_{v}=0.448$ $\mathrm{mm}$, which were the same in a previous study [13], to compare the laser peening effect on Ti6Al4V manufactured by DMLS and EBM.

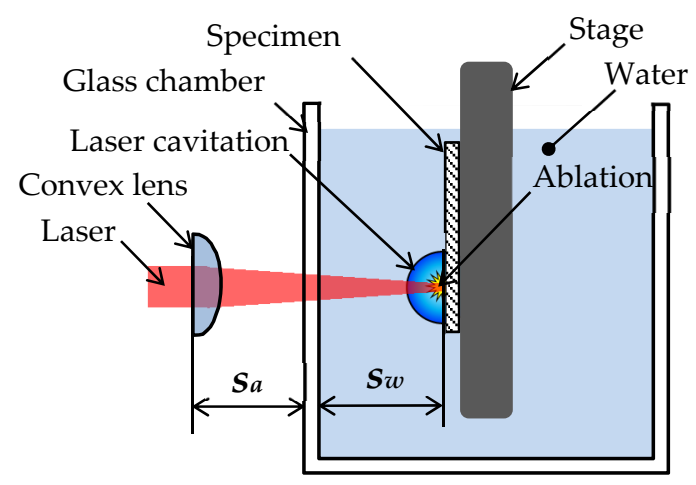

Figure 3. Schematic diagram of the peening section of the laser peening system.

\subsection{Shot Peening}

Figure 4 illustrates a schematic diagram of the peening head of the shot peening system. In the present experiment, a recirculating shot peening system accelerated by a water jet [83] was used for shot peening. Shots made of stainless-steel Japanese Industrial Standards JIS SUS440C were installed in the chamber, whose diameter was $54 \mathrm{~mm}$, and accelerated and recirculated in the chamber by the 
water jet, with an injection pressure of $12 \mathrm{MPa}$. The number and the diameter of the shots were 500 and $3.2 \mathrm{~mm}$, respectively. The water jet was injected into the chamber through three holes with a diameter of $0.8 \mathrm{~mm}$. The standoff distance from the nozzle to the specimen surface was $50 \mathrm{~mm}$. To avoid a loss of shots, the specimen was set in the recess. It should be noted that no compressive residual stress was introduced into the stainless steel without shots, so the water jet scarcely had any effect on the titanium alloy. The chamber was moved by a motor to treat the specimen surface uniformly. $t_{p}$ was defined by the scanning speed $v$ and the number of scans $n$, as shown in Equation (1). In the present experiment, $t_{p}$ was set to $1 \mathrm{~s} / \mathrm{mm}$, which was the same in a previous study [13], to compare the shot peening effect on Ti6Al4V manufactured by DMLS and EBM.

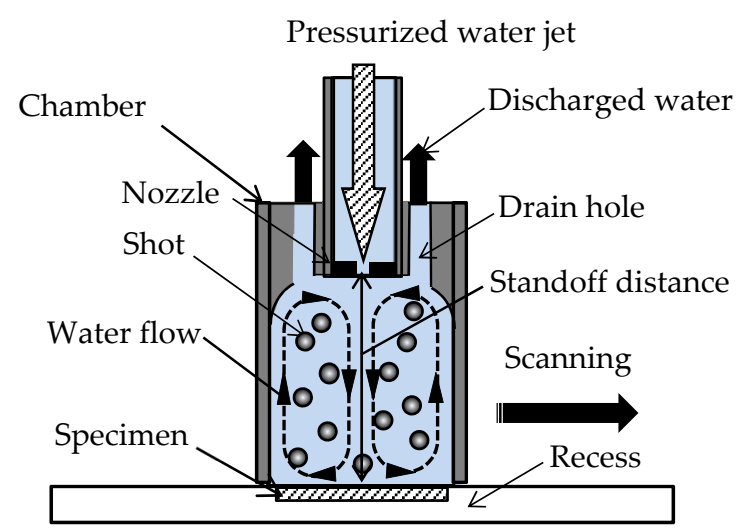

Figure 4. Schematic diagram of the peening head of the recirculating shot peening accelerated by a water jet.

\subsection{Fatigue Test and Evaluation of Surface Characteristics}

The fatigue properties of the specimens, with and without peening, were evaluated by a conventional Schenk-type displacement-controlled plane bending fatigue tester at $R=-1$. In the case of the Schenk-type displacement-controlled plane bending fatigue tester, the displacement was produced by the position of an eccentric wheel, and the applied stress was calculated from the bending moment, measured by a load cell [13]. The span length at a fixed point was $65 \mathrm{~mm}$, as shown in Figure 1, and the test frequency was $12 \mathrm{~Hz}$. The applied stress $\sigma_{a}$ at the test was calculated from the bending moment $M$, the width of the specimen $b$ (i.e., $20 \mathrm{~mm}$ ), and the thickness $\delta$ measured by a digital caliper, with an accuracy of $0.01 \mathrm{~mm}$, as shown in Equation (3).

$$
\sigma_{a}=\frac{6 M}{b \delta^{2}}
$$

As mentioned in the introduction, the fatigue properties of AM Ti6Al4V are remarkably affected by the surface roughness. Thus, the arithmetic mean roughness $R a$ and the maximum height of the roughness $R z$ were measured by a stylus type profilometer. The used cutoff length was $2.5 \mathrm{~mm}$, as the surface of the as-built AM Ti6Al4V was rough. To obtain the mean value and the standard deviation, the surface was measured three times in each case. As the bending stress was applied in the longitudinal direction in Figure 1, the surface roughness was measured in the longitudinal direction of the specimen.

In order to compare the work hardening effect of various peening methods with the as-built AM Ti6Al4V, the hardness was measured using a Rockwell superficial hardness tester and a 120 degree diamond conical indenter, with an initial load of $3 \mathrm{kgf}(29 \mathrm{~N})$ and an applied load of $15 \mathrm{kgf}$ $(147 \mathrm{~N})$, which was the same in a previous study [13]. The measured hardness was identified by $H_{R 15 \mathrm{~N}}$. The hardness was measured five times in each case to obtain the mean value and the standard deviation.

As one of the remarkable peening effects on the surface is the introduction of compressive residual stress, the residual stress $\sigma_{R}$ on the surface was measured by the 2D method [84] using an X-ray 
diffraction apparatus, with a two-dimensional detector, as the $\sin ^{2} \psi-2 \theta$ diagram of the laser peened metal was curved [85]. The optimal conditions for residual stress measurement using a 2D method, considering the error, were already reported [86]. The X-ray tube used was $\mathrm{Cu} \mathrm{K} \alpha$, and it was operated at $35 \mathrm{kV}$ and $40 \mathrm{~mA}$. The diameter of the collimator was $0.8 \mathrm{~mm}$, and the diffraction from the $8 \mathrm{~mm}$ $\times 8 \mathrm{~mm}$ area on the surface was obtained by moving the specimen perpendicularly to the $\mathrm{X}$-rays. The lattice plane $(h k l)$ used for the measurement was the Ti (213) plane, and the diffraction angle, without strain, was 139.5 degrees. The depth for the $90 \%$ contribution to the diffracted X-rays was $12.4 \mu \mathrm{m}$ in the present condition. The 24 diffraction rings from the specimen at various angles were detected, and the exposure time per frame at each single position was $5 \mathrm{~min}$. As mentioned above, the bending stress was applied in the longitudinal direction of the specimen, and the residual stress in the longitudinal direction of the specimen are discussed in the present paper.

In order to observe the surface characteristics of Ti6Al4V manufactured by DMLS and EBM, the specimen surface was observed by a laser confocal microscope and a scanning electron microscope (SEM). To distinguish the crack initiation point, the fractured surface of the specimen was also observed by SEM.

\section{Results}

\subsection{Surface Characteristics of Ti6Al4V Manufactured by DMLS and EBM}

In order to investigate the effect of various peening methods on Ti6Al4V manufactured by DMLS and EBM, Figures 5 and 6 show the aspects of specimens manufactured by DMLS and EBM, observed by a laser confocal microscope. In Figures 5 and 6, the aspect and height data, which are revealed by the color map, from blue to red, were combined to clearly show the rough surface of AM Ti6Al4V. For both the as-built specimens manufactured by DMLS and EBM, a lot of un-melted particles are on the surface, and deep valleys, whose directions are perpendicular to the stacking direction, are shown. As the averaged diameter of the used particle for DMLS and EBM is $40 \mu \mathrm{m}$ and $75 \mu \mathrm{m}$, respectively, the diameter particles on the DMLS surface are nearly half those on the surface of the EBM specimen. After cavitation peening and laser peening (see Figure $5 b, c$ and Figure $6 b, c)$, some particles were removed by impacts induced by the cavitation collapse and pulse laser. However, a lot of particles still exist on the surface. In the case of shot peening, the un-melted particles on the surface were deformed for both cases of DMLS and EBM, but deep valleys were still on the surface. As shown in Figure 5e, the deep valleys were not removed in the present grinding. In the case of cavitation peening after grinding, as shown in Figure $5 \mathrm{f}$, the valleys are more remarkable. This is probably because the burrs generated by the grinding were cleaned by the cavitation impacts. 


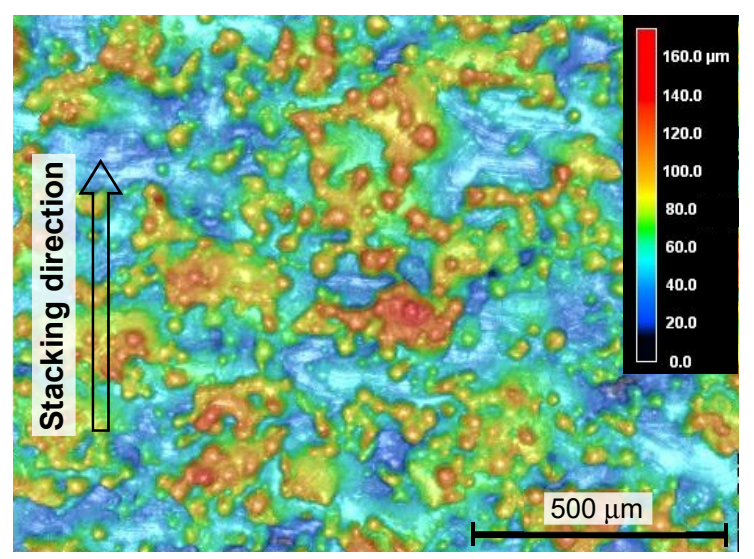

(a)

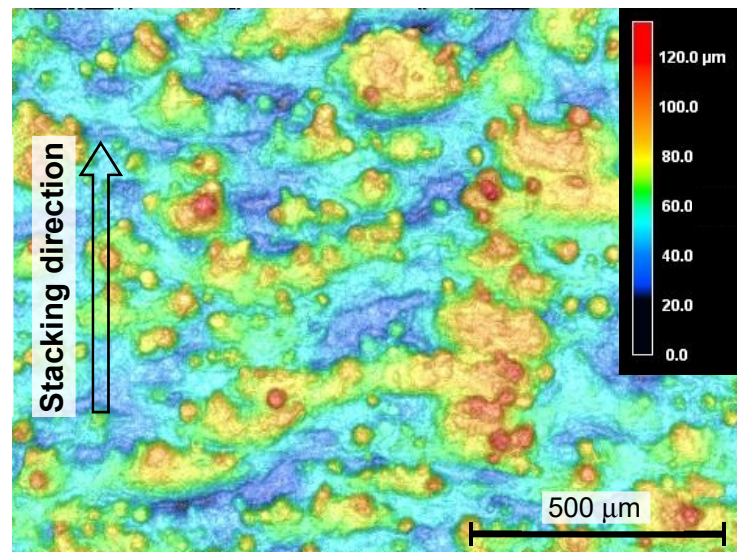

(c)

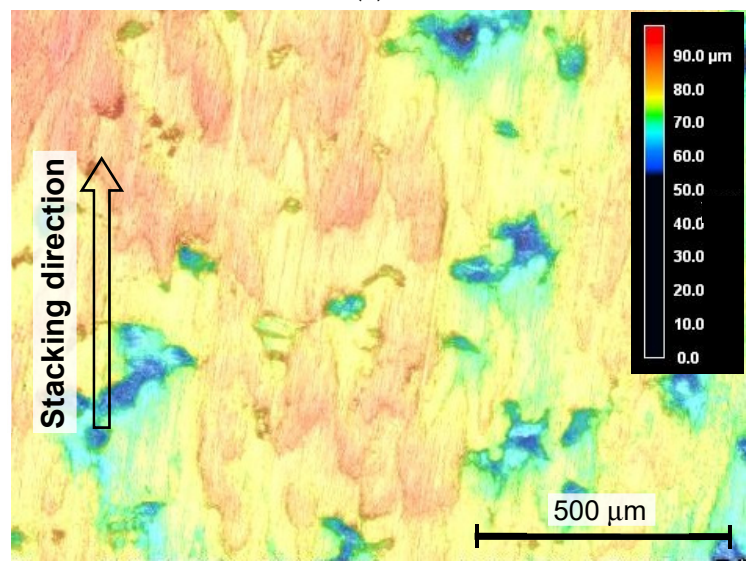

(e)

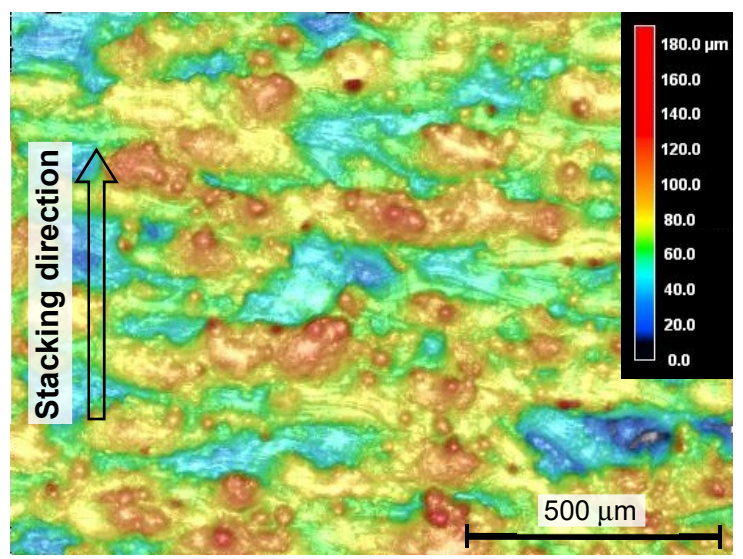

(b)

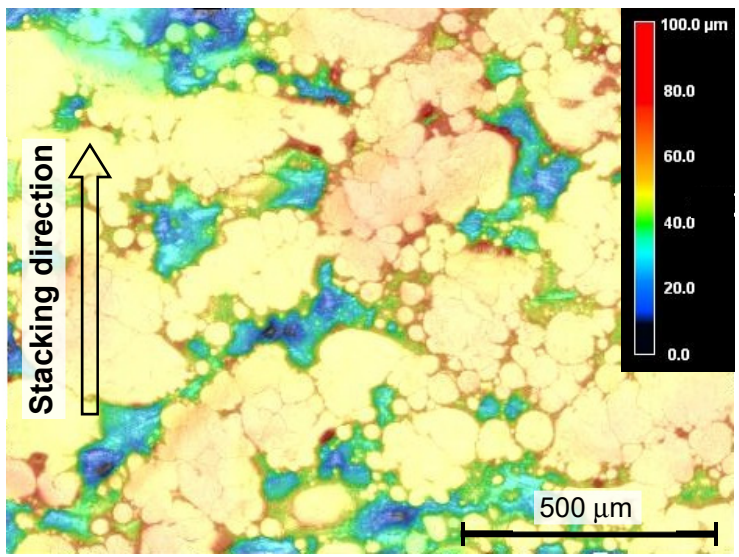

(d)

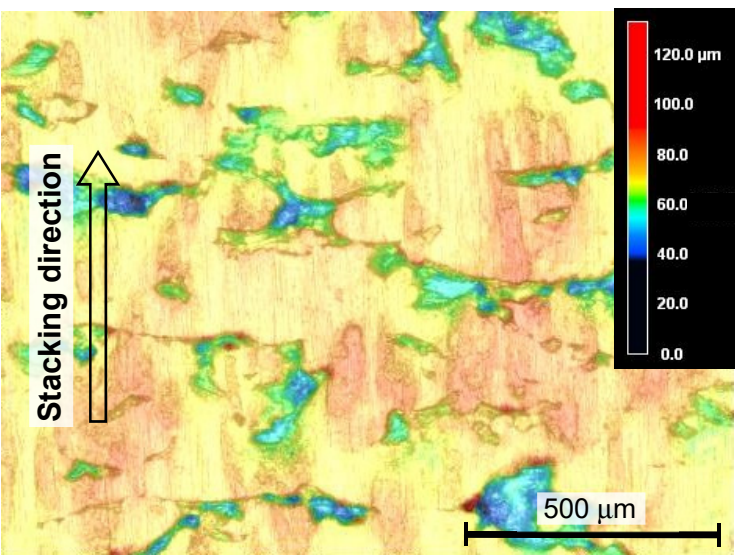

(f)

Figure 5. Aspects of the specimen manufactured by DMLS, observed by a laser confocal microscope. (a) As-built; (b) cavitation peening; (c) laser peening; (d) shot peening; (e) grinding; (f) grinding and cavitation peening. 


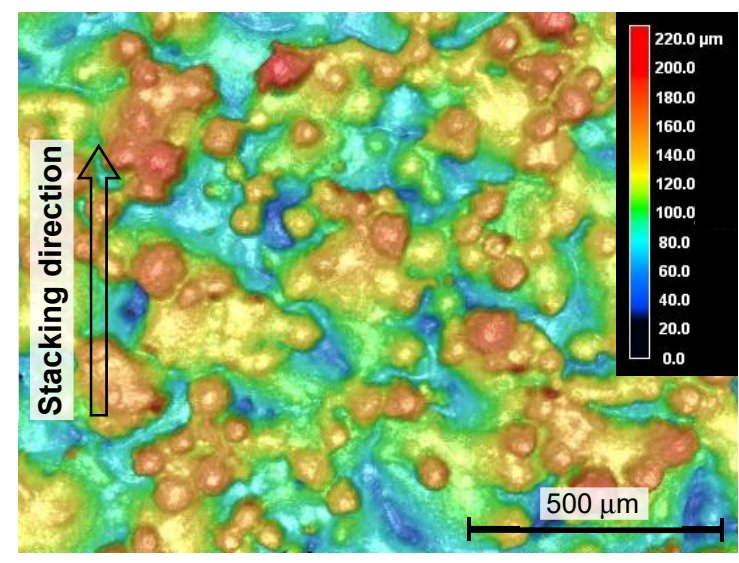

(a)

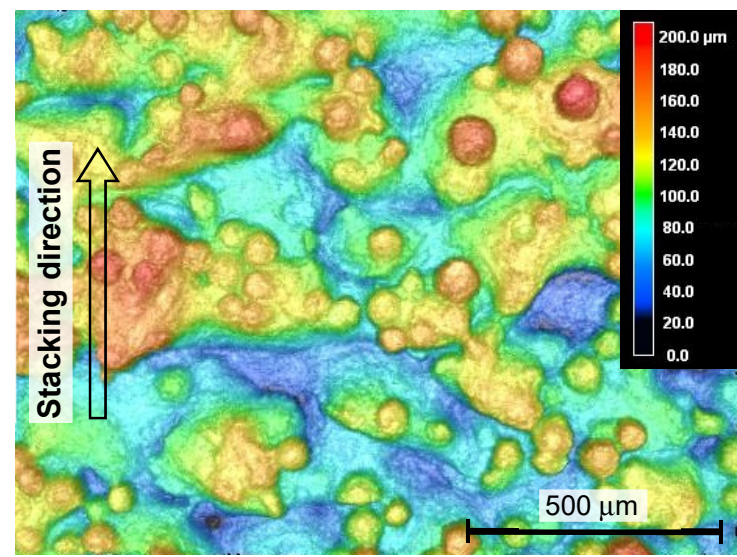

(c)

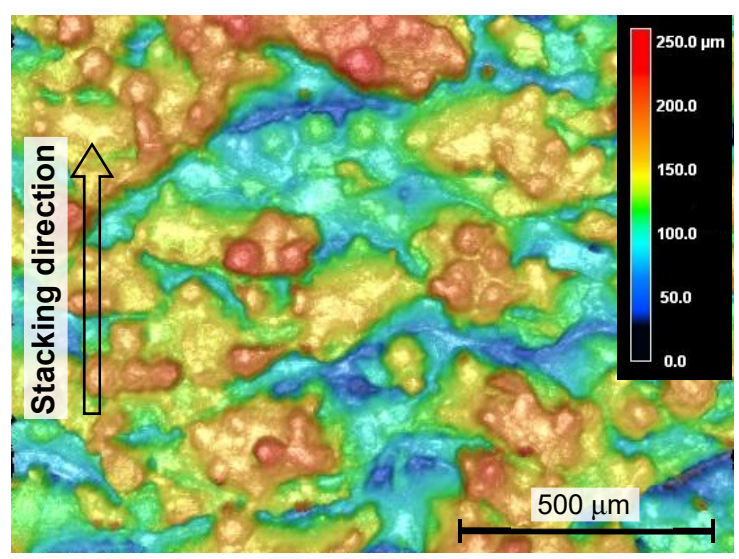

(b)

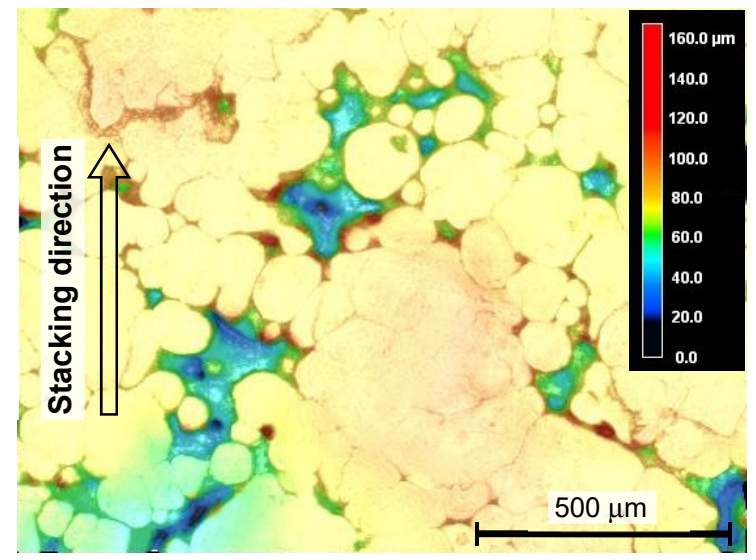

(d)

Figure 6. Aspects of the specimen manufactured by EBM, observed by a laser confocal microscope. (a) As-built; (b) cavitation peening; (c) laser peening; (d) shot peening.

In order to compare the surface roughness, with and without peening, quantitatively, Figure 7a reveals the arithmetical mean roughness $R a$, and Figure $7 \mathrm{~b}$ shows the maximum height of the roughness profile $R z$. The $R a$ and $R z$ of the as-built DMLS specimen are $11.7 \pm 1.0 \mu \mathrm{m}$ and $56.5 \pm 2.7 \mu \mathrm{m}$, respectively and those of the EBM specimen are $19.3 \pm 1.3 \mu \mathrm{m}$ and $116.1 \pm 9.9 \mu \mathrm{m}$, respectively. As shown in Figure 7, the surface of the EBM specimen is nearly two times rougher than that of the DMLS specimen, as the diameter of the used particles of the EBM specimen is about two times larger than that of the DMLS specimen. It should be noted that the $R z$ of both the DMLS and EBM specimens was 1.5 times larger than that of the diameter of the used particles. After cavitation peening, the $R z$ and $R a$ for both the DMLS and EBM specimens were slightly decreased, as some un-melted particles on the surface were removed by the cavitation impacts. On the other hand, the $R z$ and $R a$ of laser peening are nearly equivalent or slightly larger than those of the as-built specimen, even though some particles were removed from the surface by impacts induced by the laser ablation and the collapse of the bubble, which was generated after laser ablation. As mentioned in Section 2.3, the surface was treated in a $0.448 \mathrm{~mm}$ stepwise movement. Thus, a small wavy pattern in the $0.448 \mathrm{~mm}$ step was introduced by laser peening due to plastic deformation. In the case of shot peening, the $R z$ and $R a$ for both the DMLS and EBM specimens were drastically decreased by the deformation of the un-melted particles. The $R z$ and $R a$ of grinding are slightly better than those of shot peening. In the case of cavitation peening after grinding, $R z$ and $R a$ are increased, compared with those of grinding, as the burrs are removed, and the cavitation impacts produce plastic deformation pits. 


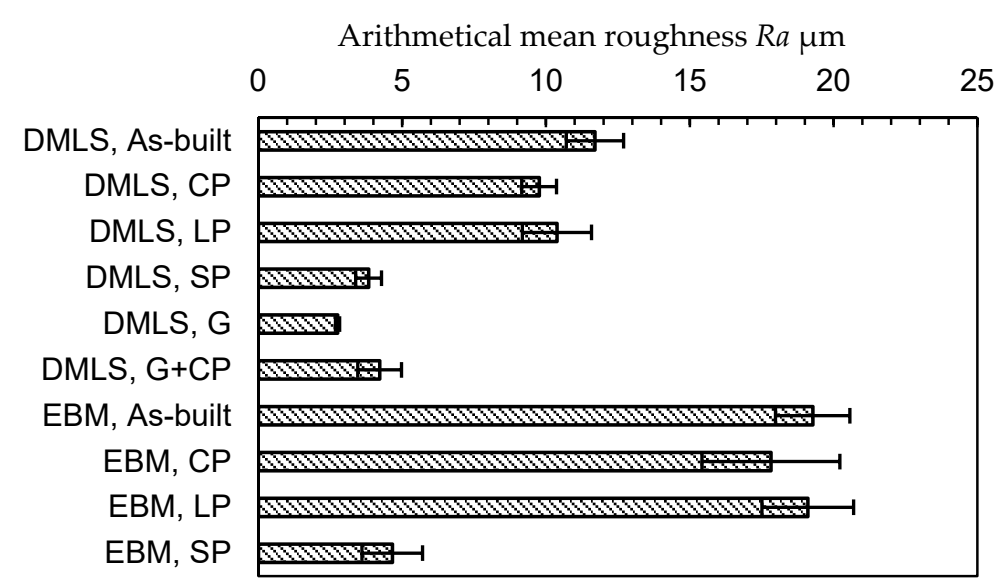

(a)

Maximum height of roughness profile $R z \mu \mathrm{m}$

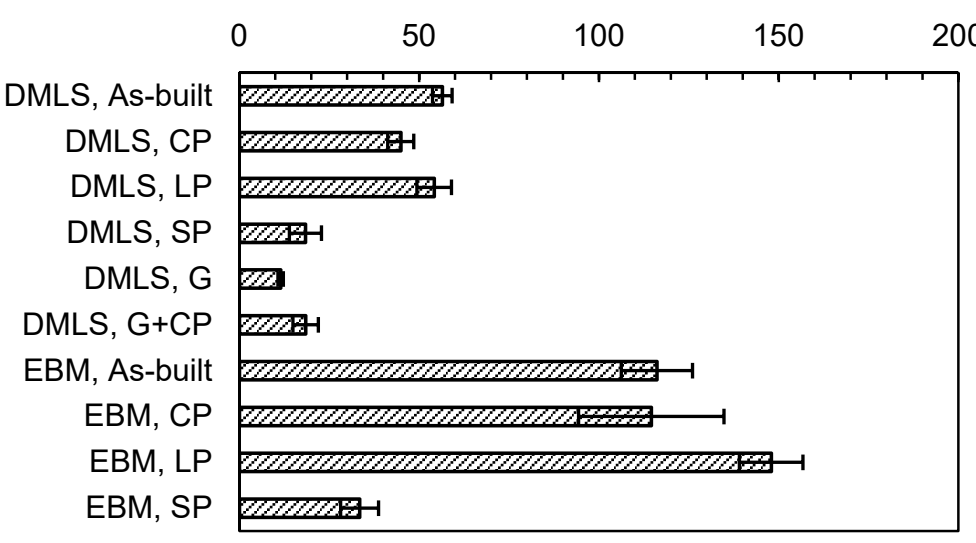

(b)

Figure 7. Surface roughness of the as-built Ti6Al4V manufactured by DMLS and EBM and the Ti6Al4V manufactured by DMLS and EBM through cavitation peening (CP), laser peening (LP), shot peeing $(\mathrm{SP})$, grinding $(\mathrm{G})$, and cavitation peening after grinding $(\mathrm{G}+\mathrm{CP})$. (a) Arithmetical mean roughness $R a$. (b) Maximum height of the roughness profile $R z$.

In order to compare the hardness of the specimens, the Rockwell superficial hardness $H_{R 15 N}$ is shown in Figure 8. As the surface of Ti6Al4V is very rough, the scatter band of $H_{R 15 N}$ in each case is relatively large. The hardness of the as-built DMLS specimen is $H_{R 15 N}=67.1 \pm 7.0$, and this is slightly harder than that of the EBM specimen (i.e., $H_{R 15 N}=61.8 \pm 6.3$ ). The $H_{R 15 N}$ of the DMLS specimen produced by cavitation peening was about $10 \%$ larger than that of the as-built Ti6Al4V, and the increment for the EBM specimen by cavitation peening was $4 \%$. In the case of laser peening, $H_{R 15 N}$ was decreased in the DMLS specimen, and it was increased in the EBM specimen. This might be caused by local melting and local plastic deformation due to the pulse laser. In the case of shot peening, $H_{R 15 N}$ was increased in both the DMLS and EBM specimens. It should be noted that $H_{R 15 N}$ was affected by the surface profile, such as the skewness $R_{s k}$ [13], and the $H_{R 15 N}$ at $R_{s k}<0$, as in the case of shot peening, was larger than that at $R_{s k}>0$, even though the hardness was equivalent. Thus, the increment on $H_{R 15 N}$ by shot peening was caused by the work hardening and deformation of the surface. In any case, the peening treatments caused a work hardening effect on both the DMLS and EBM surfaces. 


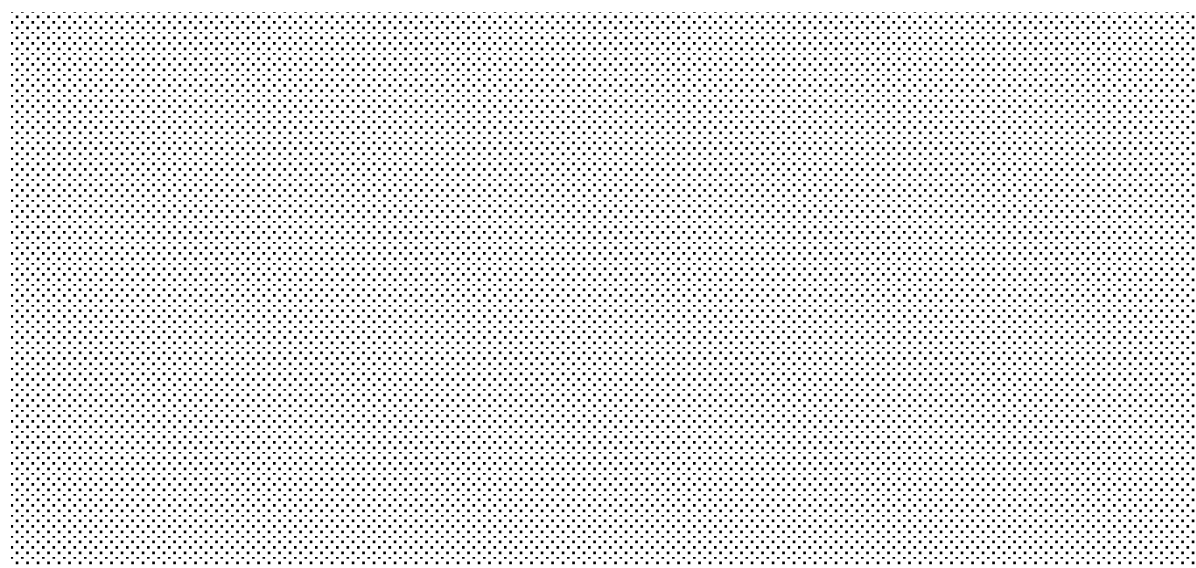

Figure 8. Surface hardness of the as-built Ti6Al4V manufactured by DMLS and EBM and the Ti6Al4V manufactured by DMLS and EBM through cavitation peening (CP), laser peening (LP), shot peeing $(S P)$, grinding $(G)$, and cavitation peening after grinding $(G+C P)$.

As residual stress $\sigma_{R}$ is also important factor for improving the fatigue strength of metallic materials by peening methods, Figure 9 shows the residual stress on the surface of the DMLS and EBM specimens, with and without treatments. The $\sigma_{R}$ of the as-built DMLS and EBM specimens is nearly zero. After cavitation peening, grinding, and shot peening, compressive residual stress was introduced. In the case of laser peening, the $\sigma_{R}$ of the DMLS specimen was tension, and the $\sigma_{R}$ of EBM was compression. As laser peening produces ablation and plastic deformation at the same time, tensile residual stress was introduced by the ablation, and compression was introduced by the peening through the plastic deformation. When $70 \mu \mathrm{m}$ of the surface of the laser-peened specimen was removed, the $\sigma_{R}$ of EBM was $-187 \pm 11 \mathrm{MPa}$. It should be noted that the depth for the $90 \%$ contribution in the residual stress measurement was about $12 \mu \mathrm{m}$, and the $R a$ of the as-built, cavitation peening and laser peening are similar. Thus, it can be concluded that the measured value of the residual stress was affected by the roughness, but all the treatments for the DMLS and EBM specimens introduced compressive residual stress into the surface (see Appendix A).

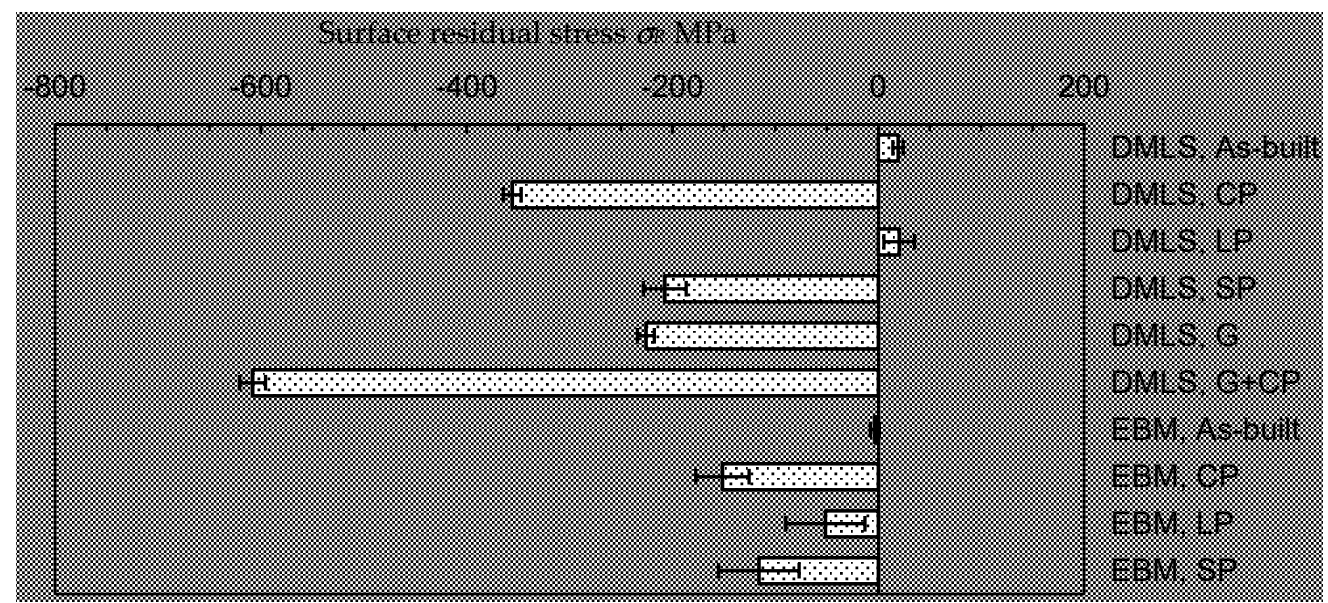

Figure 9. Surface residual stress of the as-built Ti6Al4V manufactured by DMLS and EBM and the Ti6Al4V manufactured by DMLS and EBM through cavitation peening (CP), laser peening (LP), shot peeing $(\mathrm{SP})$, grinding $(\mathrm{G})$, and cavitation peening after grinding $(\mathrm{G}+\mathrm{CP})$.

\subsection{Fatigue Properties of Ti6Al4V Manufactured by DMLS and EBM}

In order to reveal the fatigue properties of Ti6Al4V manufactured by DMLS and EBM, Figure 10 reveals the result of the plane bending fatigue test. The applied bending stress $\sigma_{a}$ in Figure 10 was calculated by Equation (3) using $\delta$, which was measured by the calipers. When the fatigue life and 
fatigue strength of the as-built specimen manufactured by DMLS and EBM were compared, those of the DMLS specimen were better than those of the EBM specimen. In the case of the DMLS specimen, the fatigue life at $\sigma_{a} \approx 450 \mathrm{MPa}$ was improved by 10 times through cavitation peening after grinding, 5.9 times through cavitation peening, 4.7 times through shot peening, 3.5 times through laser peening, and 1.5 times through grinding, compared with the as-built specimen. The fatigue strength $\sigma_{f 1}$ at $N=10^{7}$ was calculated using Little's method [87], as shown in Table 1 . The improvement ratio $R_{1}$ in Table 1 means the ratio of the fatigue strength, compared with the as-built specimen, for each DMLS and EBM specimen. The ratio $R_{2}$ in Table 1 shows the ratio between the fatigue strength of DMLS and EBM for each treatment. As shown in Figure 10 and Table 1, in the case of the DMLS specimen, the fatigue strength at $N=10^{7}$ was improved by 1.97 times through cavitation peening, 1.93 times through laser peening, 1.92 times through shot peening, and 2.41 times through cavitation peening after grinding, compared with the as-built specimen. In the case of EBM, it was improved by 1.75 times through cavitation peening, 1.87 times through laser peening, and 1.95 times through shot peening. In sum, all treatments improved the fatigue strength, and the fatigue strength of the DMLS specimen was slightly better than that of the EBM specimen, as shown in Table 1.

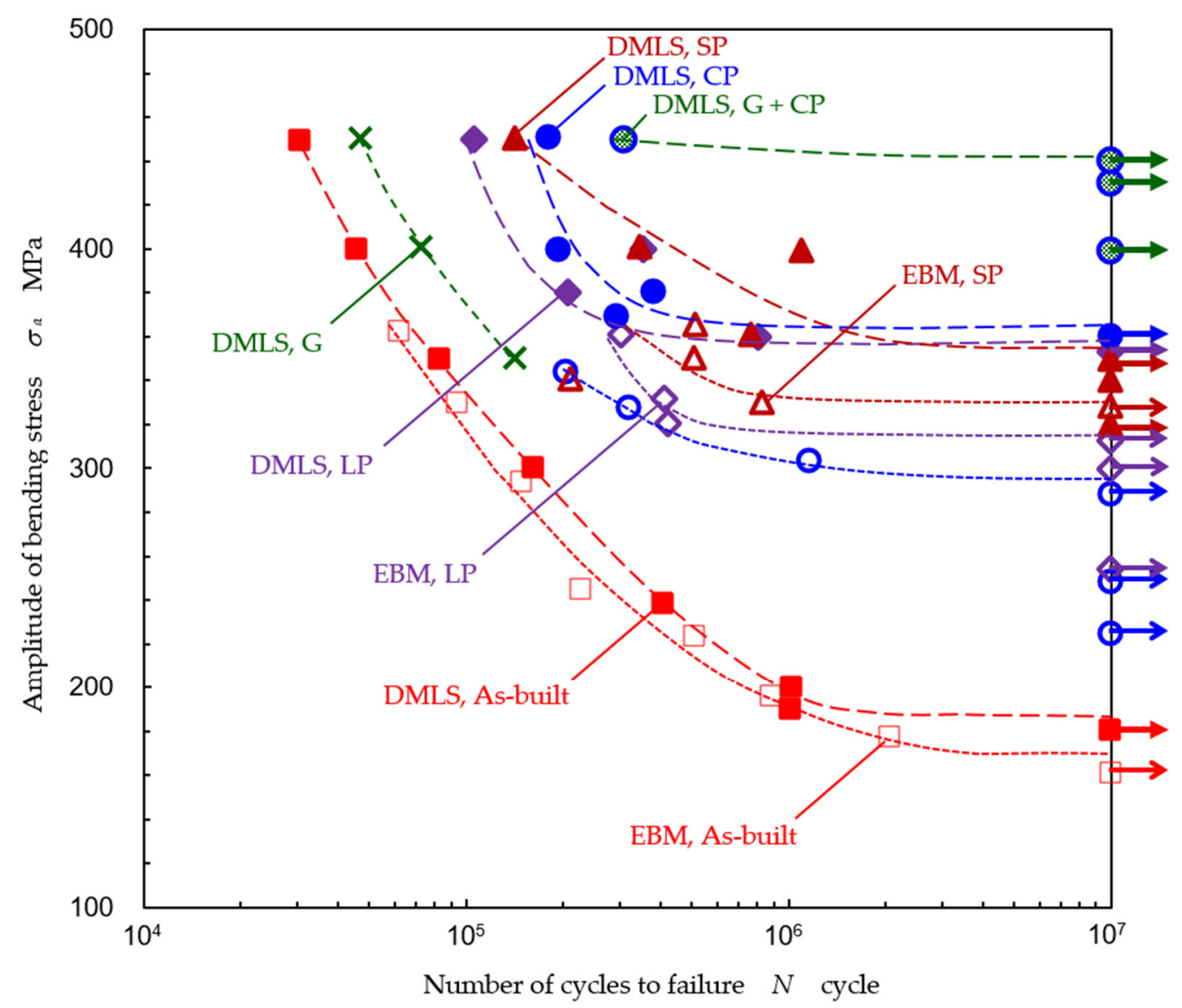

Figure 10. Improvement of the fatigue properties of Ti6Al4V manufactured by DMLS and EBM through cavitation peening $(C P)$, laser peening $(L P)$, shot peening $(S P)$ grinding $(G)$, and cavitation peening after grinding $(\mathrm{G}+\mathrm{CP})$, compared with the as-built specimen. 
Table 1. Fatigue strength and improvement ratio of the as-built Ti6Al4V manufactured by DMLS and EBM and the Ti6Al4V manufactured by DMLS and EBM through cavitation peening $(C P)$, laser peening $(L P)$, shot peeing $(S P)$, grinding $(G)$, and cavitation peening after grinding $(G+C P)$.

\begin{tabular}{ccccc}
\hline & $\begin{array}{c}\text { Number of } \\
\text { Specimens }\end{array}$ & $\begin{array}{c}\text { Fatigue Strength } \\
\boldsymbol{\sigma}_{\boldsymbol{f} \mathbf{1}} \mathbf{M P a}\end{array}$ & $\begin{array}{c}\text { Improvement } \\
\text { Ratio } \boldsymbol{R}_{\mathbf{1}}\end{array}$ & $\begin{array}{c}\text { Ratio } \\
\boldsymbol{R}_{\mathbf{2}}=\sigma_{\boldsymbol{f} \mathbf{1} \text { DMLS }} / \boldsymbol{\sigma}_{\boldsymbol{f} \mathbf{1} \text { EBM }}\end{array}$ \\
\hline DMLS, as-built & 8 & $185 \pm 9$ & 1 & 1.09 \\
DMLS, CP & 5 & $365 \pm 8$ & 1.97 & 1.23 \\
DMLS, LP & 5 & $357 \pm 6$ & 1.93 & 1.13 \\
DMLS, SP & 7 & $355 \pm 10$ & 1.92 & 1.08 \\
DMLS, G + CP & 4 & $445 \pm 8$ & 2.41 & 1 \\
EBM, as-built & 8 & $169 \pm 14$ & 1 & 1 \\
EBM, CP & 6 & $296 \pm 13$ & 1.75 & 1 \\
EBM, LP & 6 & $317 \pm 7$ & 1.87 & 1 \\
EBM, SP & 5 & $329 \pm 1$ & 1.95 & \\
\hline
\end{tabular}

\subsection{Cracks of Ti6Al4V Manufactured by DMLS and EBM}

In order to investigate the mechanism of the improvement of the fatigue properties by the treatments, Figures 11 and 12 show the aspects of the specimen surface near the fracture, observed by a scanning electron microscope (SEM), and Figures 13 and 14 reveal the fractured surface.

In Figures 11 and 12, black arrows show the cracks that were produced by the fatigue, and white arrows show the cracks that existed before the fatigue test (see Appendix B). As shown in Figures 11a and 12a, the cracks indicated by white arrows were observed on the surface of the as-built specimen, and they exist at the bottom of the valleys, which were orthogonal to the stacking direction. These cracks or steep valleys were produced during the AM process by layer-by-layer stacking. As shown in Figures $11 \mathrm{~b}$ and $12 \mathrm{~b}$, these steep valleys were opened by the cavitation attack. As the typical cavitation erosion pattern shows a jaggy pattern, the cavitation impact concentrates at the bottom of the dent. Thus, when the surface roughness was smoothed, the concentration of the cavitation impact was slightly reduced. This is a reason why the cracks at the bottom of the specimen treated by cavitation peening after grinding were fewer, compared with the specimen treated by cavitation peening without grinding. Thus, the fatigue strength of the specimen treated by cavitation peening after grinding was the best. As shown in Figures 11c and 12c, the laser-peened surface was partially melted and oxidized on the surface. In the case of shot peening, the top of the un-melted particles was deformed, as shown in Figures 11d and 12d. For both laser peening and shot peening, the cracks at the bottom of the valleys, indicated by white arrows, in the specimen, were similar to those of the as-built specimen. Moreover, the impacts produced by the pulse laser and shot collision did not open or close these cracks.

In Figures 11 and 12, the direction of the applied bending stress was in the horizontal direction. Thus, the cracks produced by the fatigue, which are indicated by the black arrows, were developed in the vertical direction, as shown in Figures 11 and 12. As is clearly shown in Figure 11b,d and Figure $12 a-d$, the cracks were initiated at the bottom of the valleys and developed. Then, it can be concluded that the weakest point of the Ti6Al4V manufactured by DMLS and EBM is where there are cracks at the bottom of the valleys, which were produced in the AM process.

In order to investigate the crack initiation point at the fatigue fracture, Figures 13 and 14 show the aspect of the fractured surface of the specimen, observed by the scanning electron microscope. The crack initiation points are shown by arrows. As is clearly shown in Figure 13a, $\mathrm{d}-\mathrm{f}$ and Figure 14a-d, the surface of the un-melted particles can be clearly observed at the crack initiation point. Thus, it can be said that the cracks were initiated at the bottom of the valleys, as mentioned above. In the present paper, these are called surface defects. When the depth of the surface defect of the as-built specimen $\delta_{d}$ was measured by the fractured surface using SEM, it was $206 \pm 43 \mu \mathrm{m}$ for the DMLS specimen and 188 $\pm 22 \mu \mathrm{m}$ for the EBM specimen. As shown in Figure $7 \mathrm{~b}$, the $R z$ of the as-built specimen was $56.5 \pm$ $2.7 \mu \mathrm{m}$ for the DMLS specimen and $116.1 \pm 9.9 \mu \mathrm{m}$ for the EBM specimen. Importantly, the $\delta_{d}$ was remarkably larger than the $R z$ for both the DMLS and EBM specimens. 


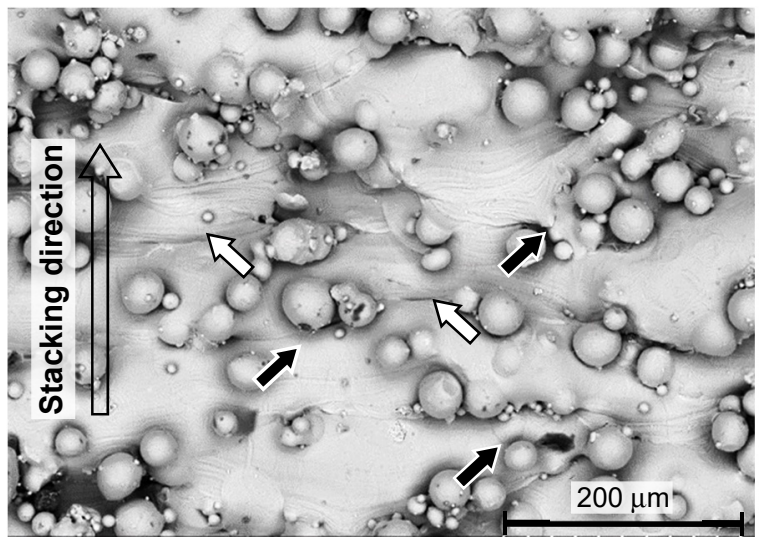

(a)

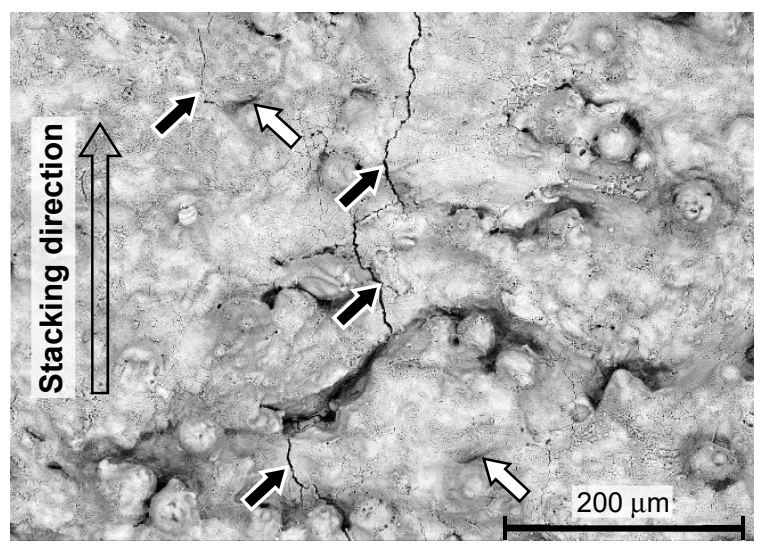

(c)

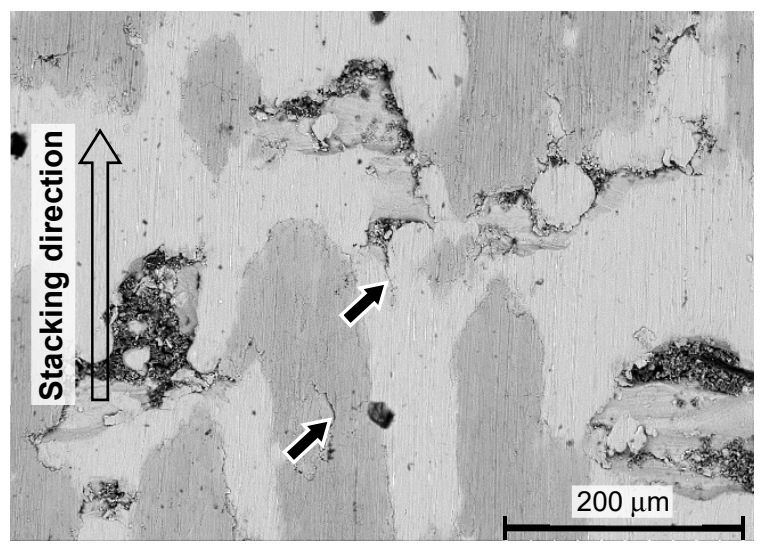

(e)

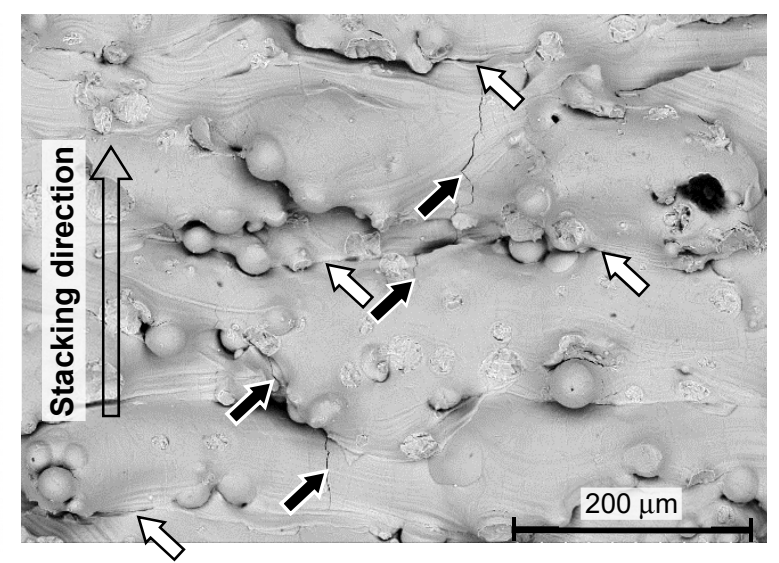

(b)

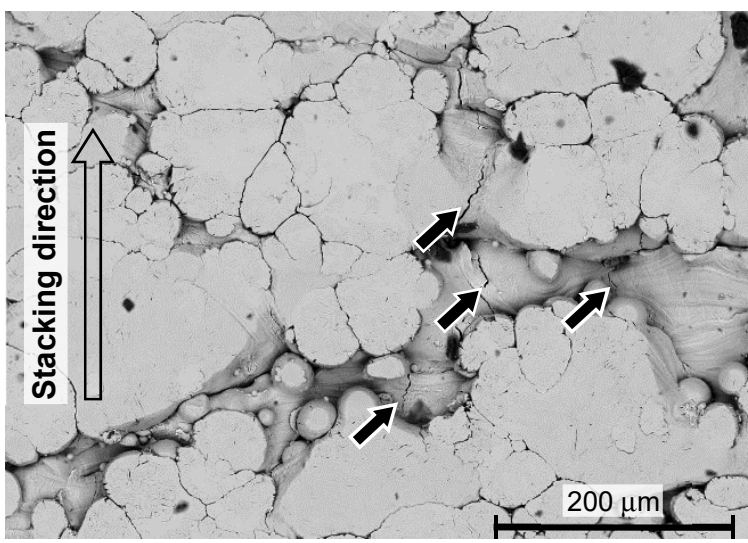

(d)

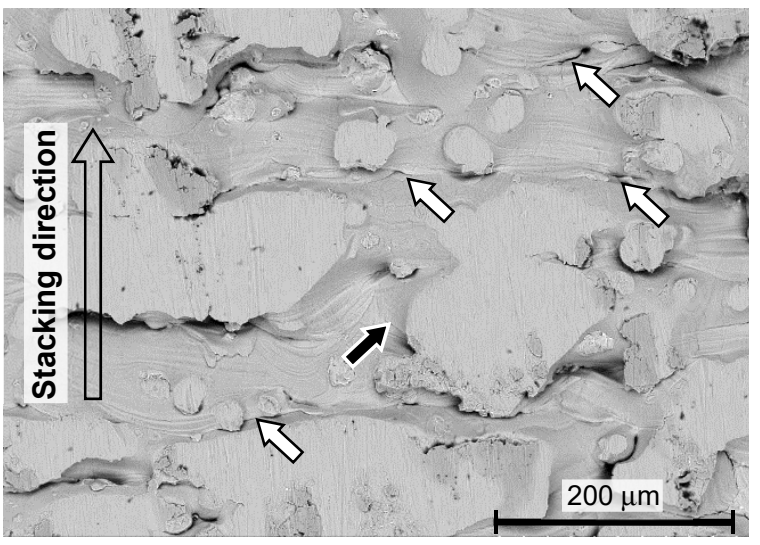

(f)

Figure 11. Aspects of the surface near the fracture of the specimen manufactured by DMLS, observed by scanning electron microscope (SEM). (a) As-built ( $\left.\sigma_{a}=301 \mathrm{MPa}, N=162,400\right)$; (b) cavitation peening $\left(\sigma_{a}=370 \mathrm{MPa}, N=291,600\right) ;(\mathbf{c})$ laser peening $\left(\sigma_{a}=400 \mathrm{MPa}, N=352,200\right) ;(\mathbf{d})$ shot peening $\left(\sigma_{a}=361\right.$ $\mathrm{MPa}, N=764,800)$; (e) grinding $\left(\sigma_{a}=350 \mathrm{MPa}, N=141,000\right)$; (f) grinding and cavitation peening $\left(\sigma_{a}=450 \mathrm{MPa}, N=310,000\right)$. 


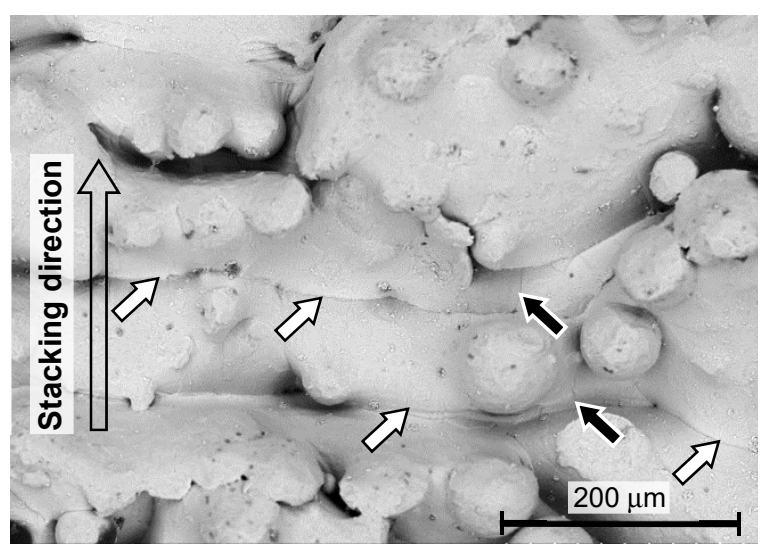

(a)

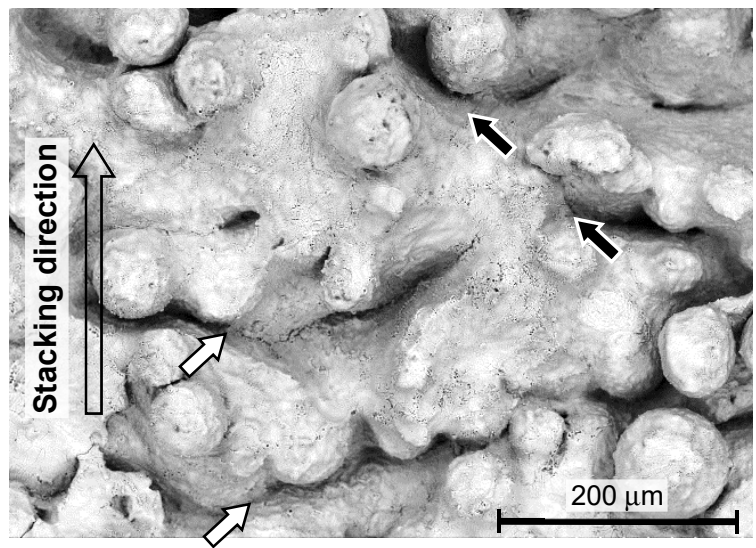

(c)

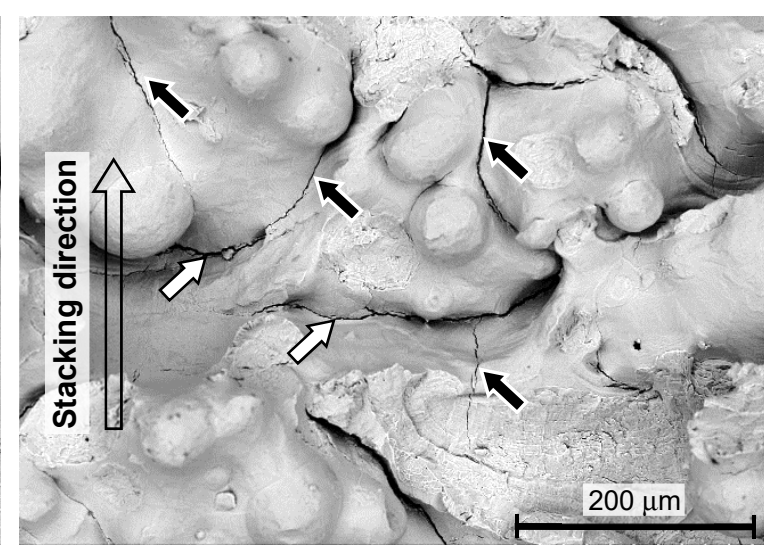

(b)

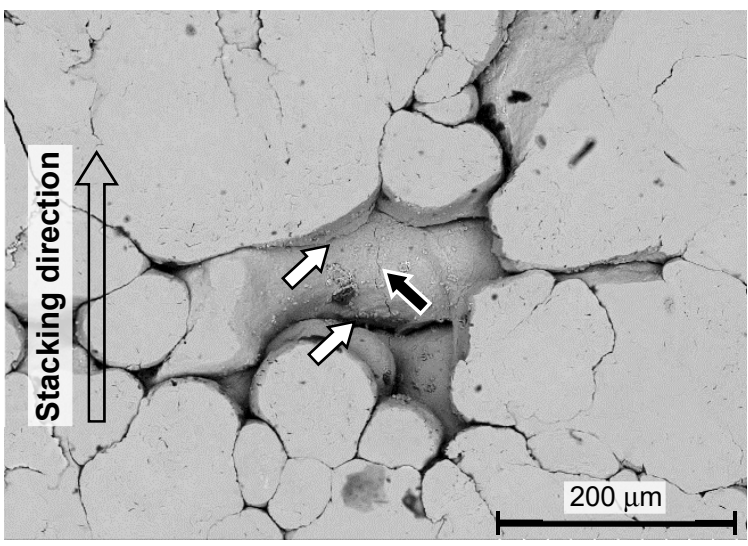

(d)

Figure 12. Aspect of the surface near the fracture of the specimen manufactured by EBM, observed by SEM. (a) As-built $\left(\sigma_{a}=224 \mathrm{MPa}, N=510,300\right)$; (b) cavitation peening $\left(\sigma_{a}=328 \mathrm{MPa}, N=319,300\right)$; (c) laser peening $\left(\sigma_{a}=320 \mathrm{MPa}, N=420,900\right)$; (d) shot peening $\left(\sigma_{a}=350 \mathrm{MPa}, N=505,700\right)$.

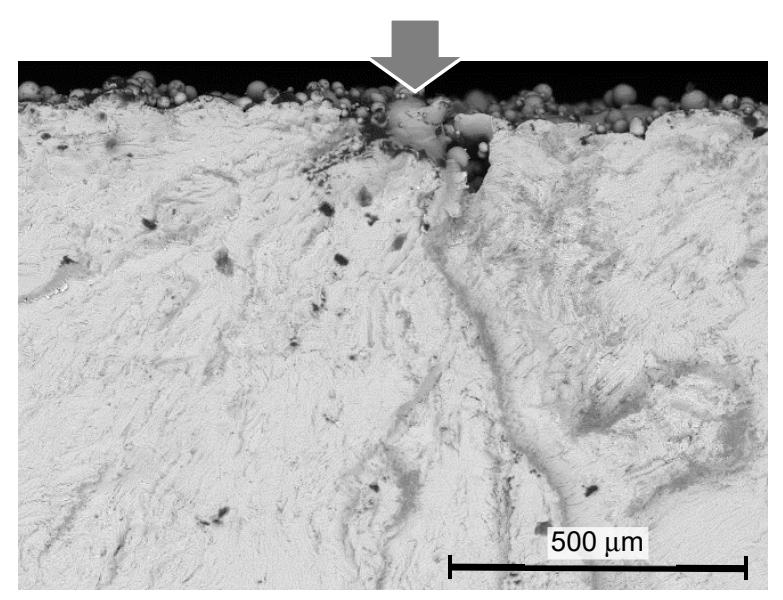

(a)

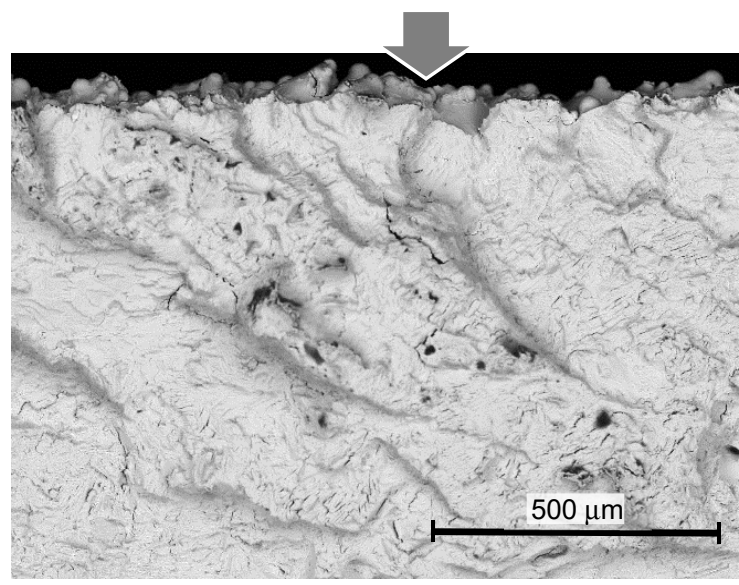

(b)

Figure 13. Cont. 


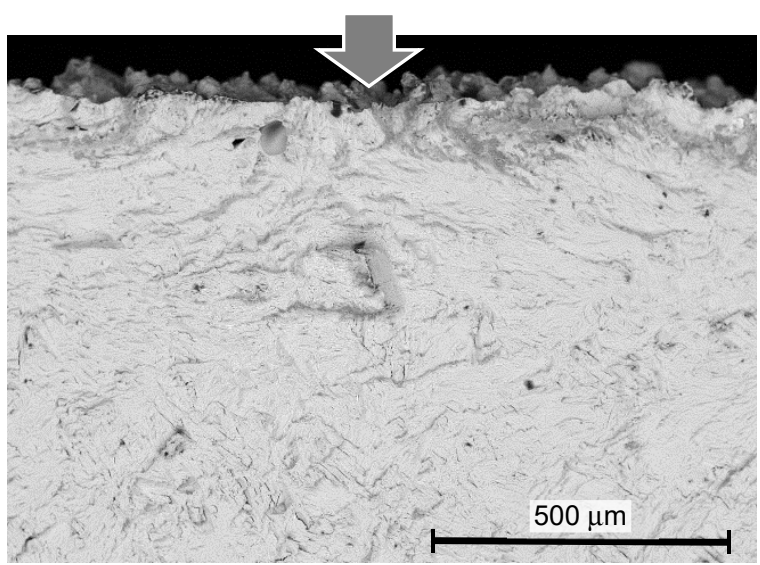

(c)

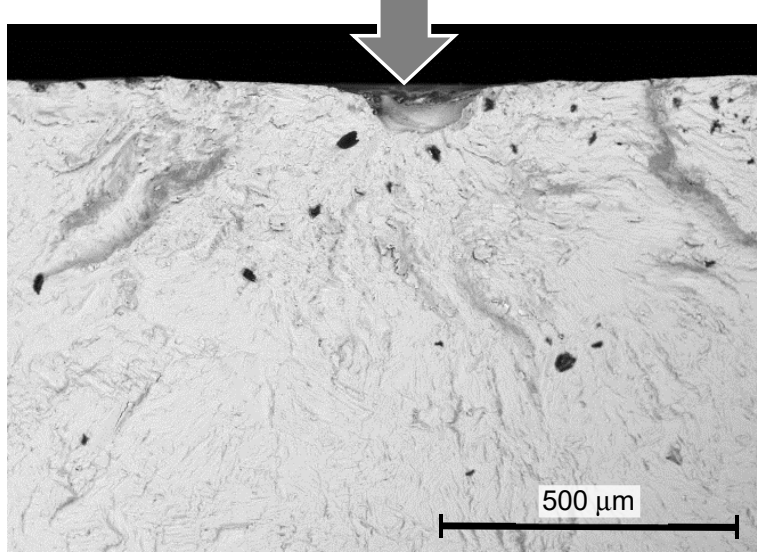

(e)

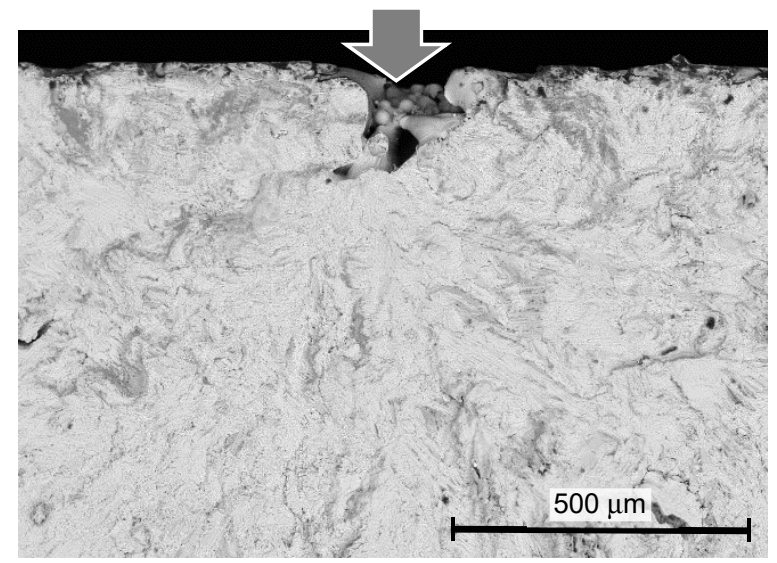

(d)

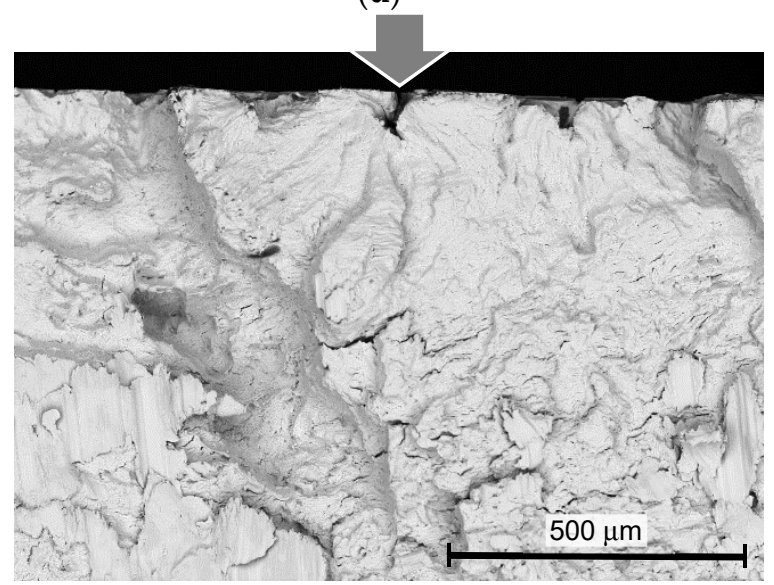

(f)

Figure 13. Aspects of the fractured surface of the specimen manufactured by DMLS, observed by SEM. (a) As-built $\left(\sigma_{a}=301 \mathrm{MPa}, N=162,400\right)$; (b) cavitation peening $\left(\sigma_{a}=370 \mathrm{MPa}, N=291,600\right)$; (c) laser peening $\left(\sigma_{a}=400 \mathrm{MPa}, N=352,200\right)$; (d) shot peening $\left(\sigma_{a}=361 \mathrm{MPa}, N=764,800\right)$; (e) grinding $\left(\sigma_{a}=350 \mathrm{MPa}, N=141,000\right) ;(\mathbf{f})$ grinding and cavitation peening $\left(\sigma_{a}=450 \mathrm{MPa}, N=310,000\right)$.

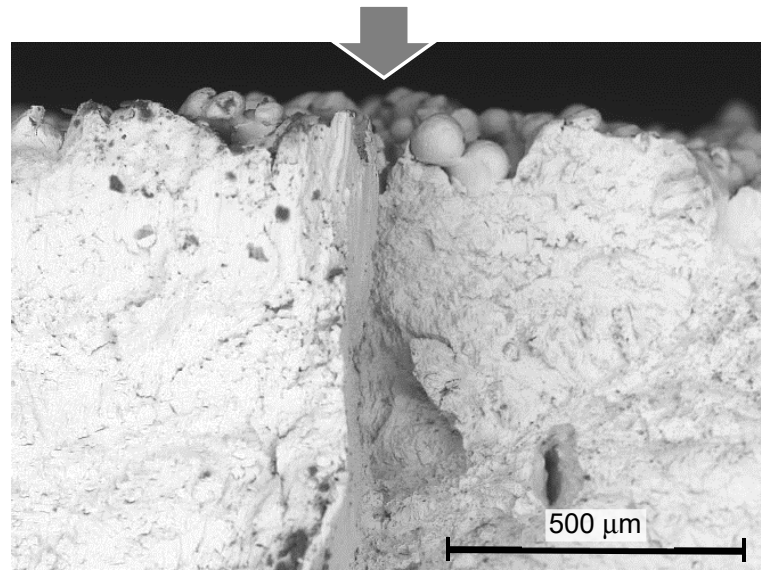

(a)

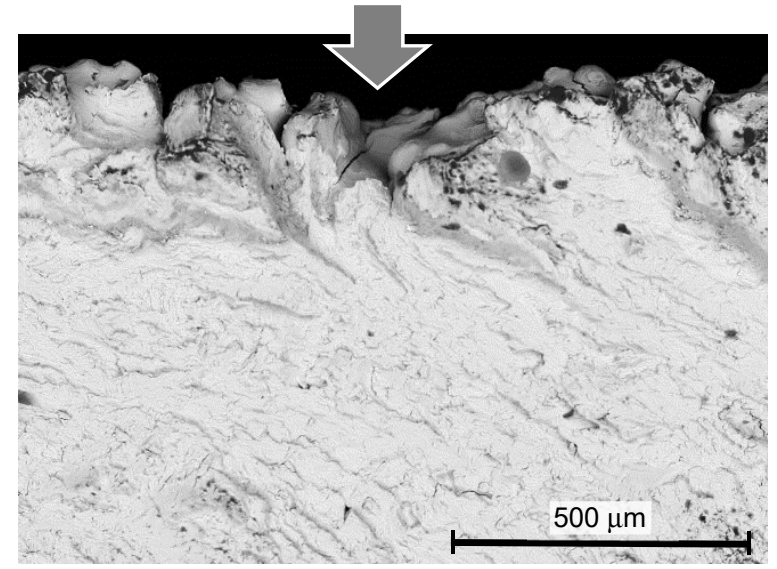

(b)

Figure 14. Cont. 


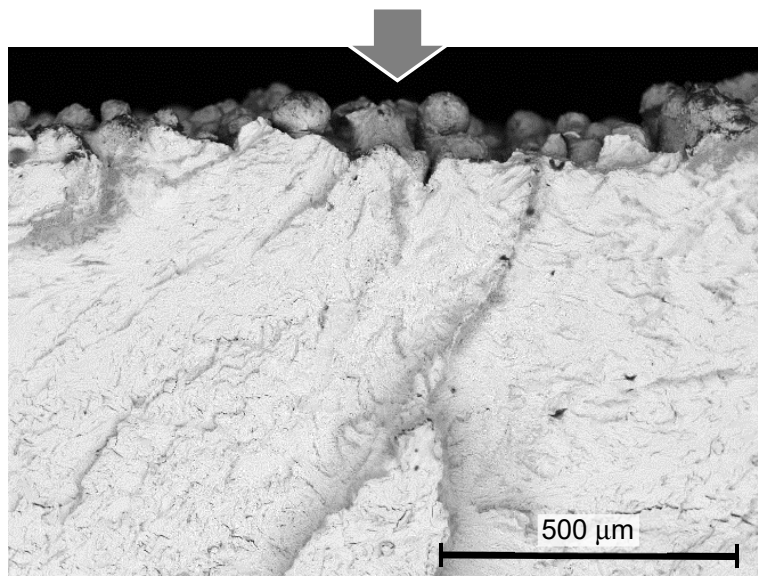

(c)

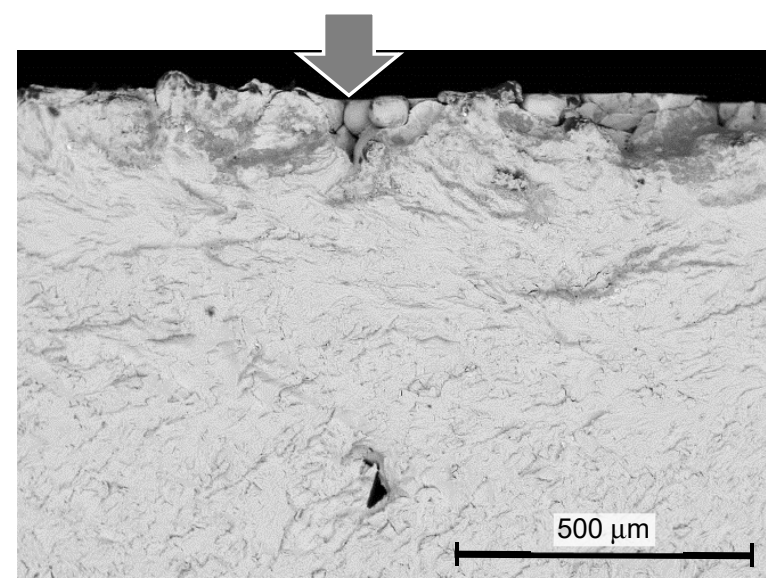

(d)

Figure 14. Aspects of the fractured surface of the specimen manufactured by EBM, observed by SEM. (a) As-built $\left(\sigma_{a}=224 \mathrm{MPa}, N=510,300\right)$; (b) cavitation peening $\left(\sigma_{a}=328 \mathrm{MPa}, N=319,300\right)$; (c) laser peening ( $\left.\sigma_{a}=320 \mathrm{MPa}, N=420,900\right)$; (d) shot peening $\left(\sigma_{a}=350 \mathrm{MPa}, N=505,700\right)$.

\section{Discussion}

\subsection{Fatigue Strength Considering the Depth of the Surface Defect}

The fatigue strength $\sigma_{f 1}$ in Table 1 was calculated with the thickness of the specimen, measured by the caliper as $\delta$ in Equation (3). In particular, the $\delta$ in Figure 15 was used as the $\delta$ in Equation (3). In the previous report, the core part $\delta$ and the surface roughness $R z$ were considered to calculate the bending stress, as shown Equation (4). Thus, $\delta$ was used as $\delta$ in Equation (3) [13]. In the present paper, the fatigue strength $\sigma_{f 2}$, considering $R z$, is shown in Table 2. As the core part is thinner than the thickness of the specimen, the increase of $\sigma_{f 2}$, compared with $\sigma_{f 1}$, was 3-9\% for the DMLS specimen and 8-43\% for the EBM specimen.

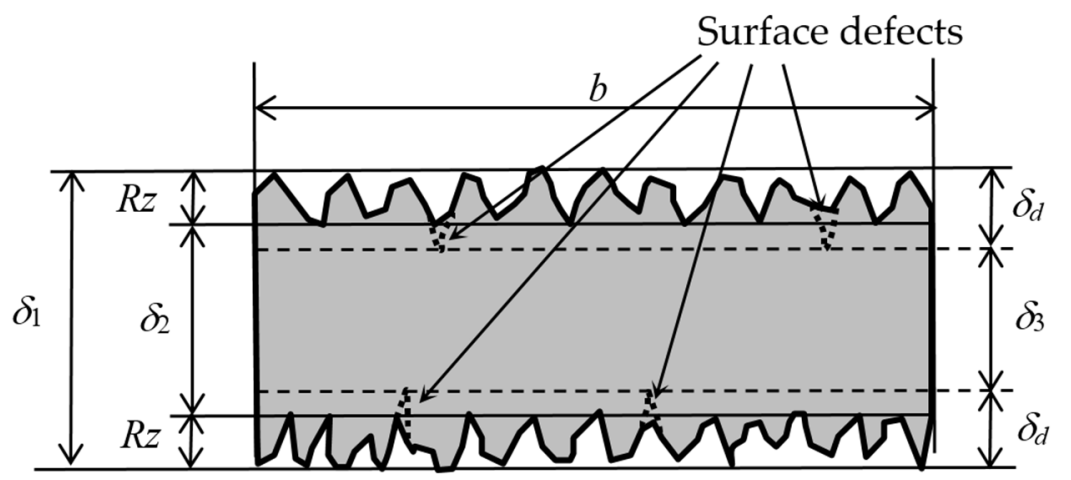

Figure 15. Schematic diagram of the thickness of the specimen for the calculation of the bending stress.

$$
\delta_{2}=\delta_{1}-2 R z
$$

As shown in Figures 13 and 14, the depth of the surface defect $\delta_{d}$ is much larger than $R z$. This means that the actual core part is thinner than $\delta_{2}$. Then, the fatigue strength $\sigma_{f 3}$ was recalculated using $\delta_{3}$, which was defined by Equation (5), instead of $\delta_{2} \cdot \sigma_{f 3}$ is shown in Table 2. It should be noted that $\delta_{d}$ is $206 \mu \mathrm{m}$ for the DMLS specimen and $188 \mu \mathrm{m}$ for the EBM specimen in the present study.

$$
\delta_{3}=\delta_{1}-2 \delta_{d}
$$


The $\sigma_{f 3}$ of the DMLS specimen was $561 \pm 12 \mathrm{MPa}$ for cavitation peening after grinding and $497 \pm 12 \mathrm{MPa}$ for cavitation peening. Elsewhere [88], the fatigue strength at $10^{7}$ of the bulk material made of Ti6Al4V through heat treatment was $545 \pm 10 \mathrm{MPa}$. The fatigue strength of the present Ti6Al4V manufactured by DMLS was about $50 \%$ of the bulk Ti6Al4V, and it was improved by up to $90 \%$ of the bulk Ti6Al4V by cavitation peening, and it came to have a nearly equivalent strength to the bulk Ti6Al4V.

Table 2. Fatigue strength considering the roughness and defect of the as-built Ti6Al4V manufactured by DMLS and EBM and the Ti6Al4V manufactured by DMLS and EBM through cavitation peening $(\mathrm{CP})$, laser peening $(\mathrm{LP})$, shot peeing $(\mathrm{SP})$, grinding $(\mathrm{G})$, and cavitation peening after grinding $(\mathrm{G}+\mathrm{CP})$.

\begin{tabular}{ccc}
\hline & Fatigue Strength $\sigma_{f 2} \mathbf{M P a}$ & Fatigue Strength $\sigma_{f 3}$ MPa \\
\hline DMLS, as-built & $202 \pm 10$ & $262 \pm 18$ \\
DMLS, CP & $392 \pm 9$ & $497 \pm 13$ \\
DMLS, LP & $389 \pm 6$ & $494 \pm 8$ \\
DMLS, SP & $366 \pm 10$ & $467 \pm 12$ \\
DMLS, G + CP & $459 \pm 8$ & $561 \pm 12$ \\
EBM, as-built & $221 \pm 19$ & $262 \pm 17$ \\
EBM, CP & $388 \pm 18$ & $442 \pm 16$ \\
EBM, LP & $451 \pm 6$ & $474 \pm 30$ \\
EBM, SP & $355 \pm 1$ & $468 \pm 7$ \\
\hline
\end{tabular}

\subsection{Experimental Formula to Estimate Fatigue Strength Improved by Mechanical Surface Treatments}

In order to evaluate the effect of the surface roughness, surface hardness, and residual stress on the improvement of the fatigue strength by mechanical surface treatment, the experimental formula to estimate the improved fatigue strength $\sigma_{f}$ est by mechanical surface properties was proposed in Equation (6). In Equation (6), $\sigma_{f 0}$ is the fatigue strength of the reference condition. It was reported that the fatigue strength was decreased with the maximum surface roughness [39], equivalent crack length of the defect [43], and root area parameter [44]. Thus, the parameter of the surface roughness should be placed in the denominator, as shown in the second term of the right-side member of Equation (6). The hardness suggests the tendency of the increase of the yield stress of the surface by the mechanical surface treatments, and the hardness is expressed in Equation (6) as in the third term. As the residual stress affects the fatigue properties of AM Ti6Al6V [15], $\sigma_{R}$ is placed in the fourth term. $\Delta R z^{\prime}$ and $\Delta H_{R N T}{ }^{\prime}$ are the differences in $R z$ and $H_{R N T}$ between the reference condition and the estimated condition, normalized by the reference condition, as shown in Equations (7) and (8). The $\Delta \sigma_{R}$ is the difference in residual stress between the estimated condition and the reference condition. In particular, the second term of the right-side member of Equation (6) reveals the effect of surface roughness. The third term shows the effect of work hardening (i.e., an increase of hardness). The fourth term reveals the effect of residual stress. The second term and the third term were normalized by the reference values.

$$
\begin{gathered}
\sigma_{f \text { est }}=\sigma_{f 0}+a \frac{1}{\Delta R z \prime} \sigma_{f 0}+b \Delta H_{R 15 N^{\prime}} \sigma_{f 0}+c \Delta \sigma_{R} \\
\Delta R z^{\prime}=\frac{R z_{0}-R z}{R z_{0}} \\
\Delta H_{R 15 N^{\prime}}=\frac{H_{R 15 N}-H_{R 15 N 0}}{H_{R 15 N 0}} \\
\Delta \sigma_{R}=\sigma_{R}-\sigma_{R 0}
\end{gathered}
$$

Here, $a, b$, and $c$ are the constants calculated using the least squares method, and they reveal the contributions of the surface roughness, surface hardness, and residual stress, to the improvement of fatigue strength. The obtained constants are shown in Table 3 , and the relationship between the experimental fatigue strength $\sigma_{f 1}, \sigma_{f 2}$, and $\sigma_{f 3}$ and the estimated fatigue strength $\sigma_{f 1 ~ e s t}, \sigma_{f 2}$ est , and $\sigma_{f 3}$ est 
is shown in Figure 16. The error bars in Figure 16 were calculated from the standard deviation of the measured values (i.e., $\sigma_{f 1}, R z, H_{R N T}$, and $\sigma_{R}$ ) using error analysis [89]. In Table 3 and Figure 16, the values of the as-built EBM specimen were used as the reference condition to estimate the fatigue strength. In the estimation, the residual stress of laser peening was $-187 \pm 11 \mathrm{MPa}$, as compressive residual stress was introduced in the near surface, although the surface was abraded by laser ablation. As shown in Figure 16, the relations between the experimental fatigue strength and the estimated fatigue strength for all three cases (i.e., $\sigma_{f 1}-\sigma_{f 1}$ est,$\sigma_{f 2}-\sigma_{f 2}$ est , and $\sigma_{f 3}-\sigma_{f 3}$ est , are roughly on the line. These results show that the improved fatigue strength of the AM titanium alloy, enhanced by surface mechanical treatments, can be estimated from the fatigue strength of the as-built specimen by measuring the surface roughness, surface hardness, and surface residual stress of the treated one using Equation (6). Now, let us investigate the effect of the surface roughness, surface hardness, and surface residuals stress in the improvement of the fatigue strength. As mentioned above, although the surface roughness of the cavitation peened and laser peened specimens were scarcely changed, the fatigue strength was drastically improved by both peening methods. This means that the effect of the surface roughness was smaller than the others in the present study. This is why $a$ is relatively smaller than $b$ and $c$. When the absolute values of $a, b$, and $c$ were compared, the absolute value of $b$ was relatively larger than the others. In particular, the contribution of $H_{R 15 N}$ was relatively large, and the scatter band of $H_{R 15 N}$ was relatively large, as shown in Figure 8. Thus, the scatter band of the estimated fatigue strength was relatively large, as shown in Figure 16. As the compressive residual stress (i.e., negative value) enhances the fatigue strength, $c$ is negative. As shown in Table 3 , the absolute value of $c$ was 0.34 for $\sigma_{f 1}-\sigma_{f 1 ~ e s t}, 0.38$ for $\sigma_{f 2}-\sigma_{f 2 \text { est }}$, and 0.39 for $\sigma_{f 3}-\sigma_{f 3}$ est. As the plane bending fatigue test was used in the present study, and the maximum bending stress was applied at the surface, the fatigue strength was improved by $34-39 \%$ of the introduced compressive residual stress. As shown in Figure 16, the laser peening points for both the DMLS and EBM specimens are slightly further than the others, as the measured work hardening was not so large, compared with the other treatments. The correlation coefficient between the experimental fatigue strength and the estimated value was 0.896 for $\sigma_{f 1}-\sigma_{f 1}$ est, 0.766 for $\sigma_{f 2}-\sigma_{f 2 ~ e s t}$, and 0.823 for $\sigma_{f 3}-\sigma_{f 3}$ est. As the number of the dataset was nine in the present study, the probability of a non-correlation is less than $0.1 \%$ for $\sigma_{f 1}-\sigma_{f 1 \text { est }}, 1.6 \%$ for $\sigma_{f 2}-\sigma_{f 2 \text { est }}$, and $0.6 \%$ for $\sigma_{f 3}-\sigma_{f 3}$ est. When the probability of a non-correlation is less than $1 \%$, it can be concluded that the relationship is highly significant. Thus, it can be concluded that the relationship between the experimental fatigue strength and the estimated fatigue strength is highly significant. In particular, the improved fatigue strength treated by the present post-processing can be estimated by the surface roughness, surface hardness, and surface residual stress.

Table 3. Constants to estimate the improved fatigue strength of the Ti6Al4V manufactured by DMLS and EBM through mechanical surface treatment using the surface roughness, surface hardness, and surface residual stress.

\begin{tabular}{cccc}
\hline Constant & $\sigma_{f 1 \text { est }}$ & $\sigma_{f 2 \text { est }}$ & $\sigma_{f 3 \text { est }}$ \\
\hline$a$ & 0.01 & 0.01 & 0.01 \\
$b$ & 2.59 & 1.17 & 1.95 \\
$c$ & -0.34 & -0.38 & -0.39 \\
\hline
\end{tabular}




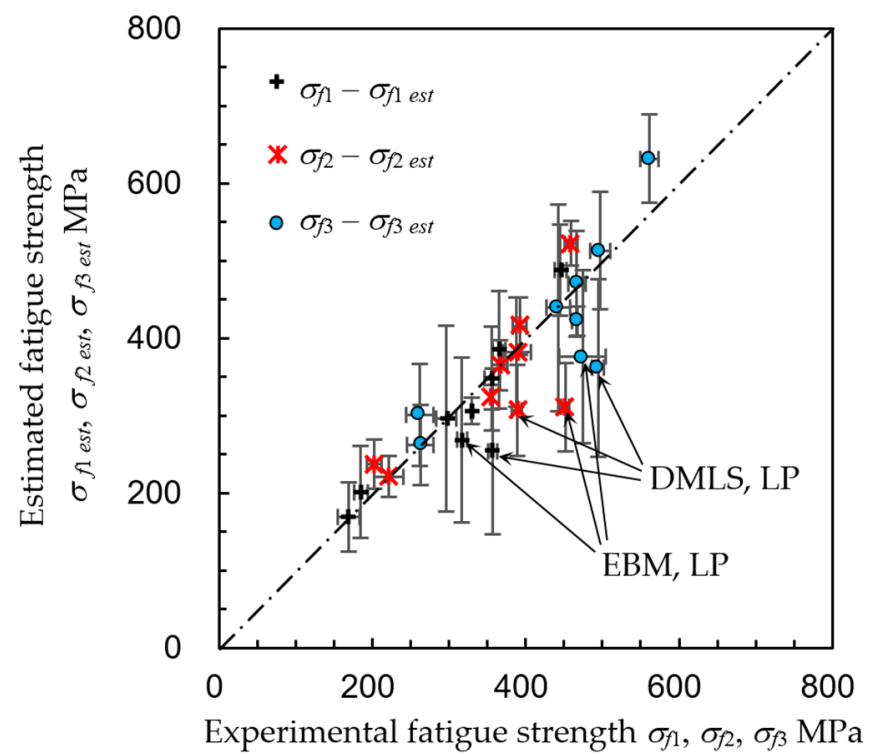

Figure 16. Relationship between the experimental fatigue strength and fatigue strength estimated from the surface roughness, surface hardness, and surface residual stress.

\section{Conclusions}

In order to establish post-processing for the improvement of the fatigue strength of the additive manufactured (AM) Ti6Al4V, Ti6Al4V manufactured by direct metal laser sintering (DMLS) and electron beam melting (EBM) was treated by cavitation peening, laser peening, and shot peening, and the fatigue properties were evaluated by the displacement-controlled plane bending fatigue test. To clarify the mechanism of the improvement of the fatigue strength by mechanical surface treatments, the surface mechanical properties were measured, and the experimental formula to estimate the improved fatigue strength from the mechanical surface properties was discussed to compare the contribution of each parameter. The results obtained can be summarized as follows:

(1) Cavitation peening, laser peening, and shot peening can improve the fatigue strength of Ti6Al4V manufactured by DMLS and EBM. In the case of DMLS, the improvements in the fatigue strength at $N=10^{7}$, compared with that of the as-built specimen, were $97 \%$ for cavitation peening, $93 \%$ for laser peening, and $92 \%$ for shot peening in the present condition. In the case of EBM, they were $75 \%$ for cavitation peening, $87 \%$ for laser peening, and $95 \%$ for shot peening in the present condition.

(2) The fatigue strength of Ti6Al4V manufactured by DMLS is slightly better than that manufactured by EBM, with and without peening. The difference in fatigue strength at $N=10^{7}$ between the DMLS and EBM specimens was $+9 \%$ for the as-built specimen, $+23 \%$ for the cavitation peening specimen, $+13 \%$ for the laser peening specimen, and $+8 \%$ for the shot peening specimen.

(3) The fatigue strength of the Ti6Al4V manufactured by DMLS treated by cavitation peening was improved to the same level as that of wrought Ti6Al4V, when the depth of the surface defects was considered in the calculation of the fatigue strength. The fatigue strength at $N=10^{7}$ of the DMLS specimen was $497 \mathrm{MPa}$ for cavitation peening and $561 \mathrm{MPa}$ for cavitation peening after grinding the surface.

(4) The improvement of the fatigue strength of AM Ti6Al4V caused by the treatments can be estimated using the surface roughness, surface hardness, and residual stress.

Author Contributions: Conceptualization, H.S. and F.T.; methodology, H.S.; validation, H.S. and F.T.; formal analysis, H.S.; investigation, H.S.; resources, H.S.; data curation, H.S.; writing-original draft preparation, H.S.; writing-review and editing, H.S. and F.T.; funding acquisition, H.S. All authors have read and agreed to the published version of the manuscript. 
Funding: This research was partly supported by JSPS KAKENHI, grant number 18KK0103 and $20 \mathrm{H} 02021$.

Acknowledgments: The authors are grateful to Tohoku Science, Co., Ltd. for providing a desktop-type scanning electron microscope, Miniscope TM4000Plus II.

Conflicts of Interest: The authors declare no conflicts of interest.

\section{Appendix A}

Figure A1 shows X-ray diffraction patterns for Ti6Al4V manufactured by DMLS and EBM. As shown in Figure A1, the X-ray diffraction patterns after the treatments are wider, compared with that of the as-built specimen. There are two main reasons: One is that the local plastic deformation is the same as the mechanical surface treatment of metallic materials, including wrought samples. The peening methods used and grinding produce local plastic deformation, and the local plastic deformation produces compressive residual stress and lattice fluctuations. The other reason is the surface roughness caused by the AM process. Figure A2 shows a schematic diagram of the surface roughness and depth for a $90 \%$ contribution of $X$-ray diffraction. As mentioned in Section 2, the average diameter of the particle used was used $40 \mu \mathrm{m}$ for the DMLS process and $75 \mu \mathrm{m}$ for the EBM process, and the depth for the $90 \%$ contribution of diffracted X-rays was $12.4 \mu \mathrm{m}$ in the present condition. The compressive residual stress introduced at the top of the un-melted particle was relatively low, compared with that in the flat area, as shown in Figure A2. The difference in compressive residual stresses also causes a widening of the X-ray diffraction profile, as the peaks in each area are also different. Thus, it can be concluded that the measured value of the residual stress was affected by the roughness, but all the treatments for the DMLS and EBM specimens introduced compressive residual stress at the surface.

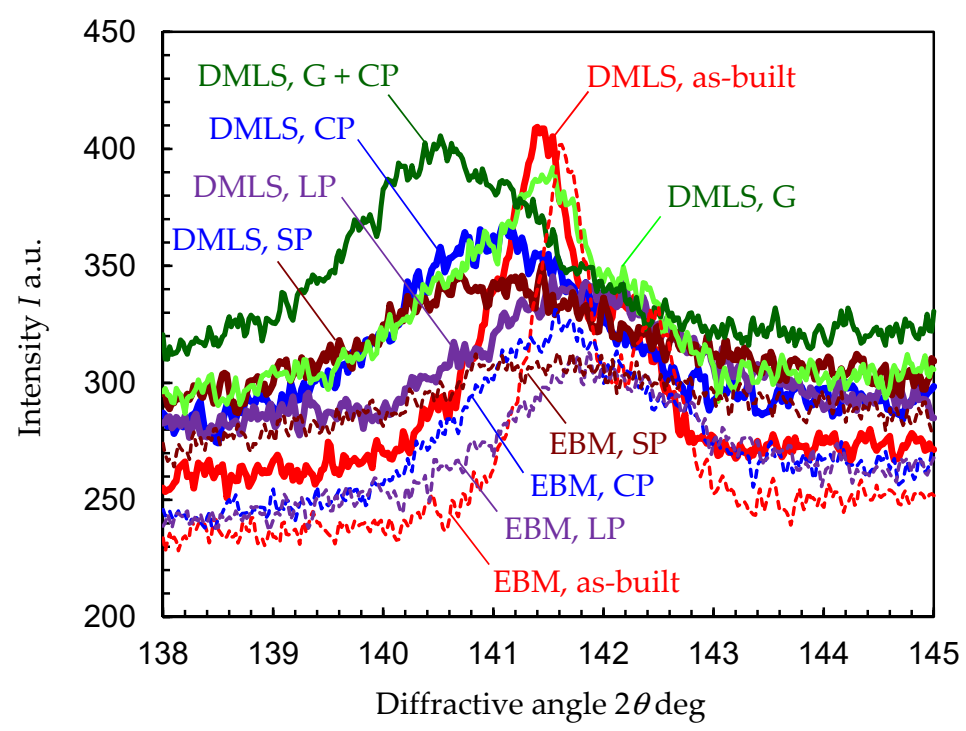

Figure A1. X-ray diffraction pattern for the Ti6Al4V manufactured by DMLS and EBM through cavitation peening $(\mathrm{CP})$, laser peening (LP), shot peening (SP) grinding $(\mathrm{G})$, and cavitation peening after grinding $(\mathrm{G}+\mathrm{CP})$, compared with the as-built specimen.

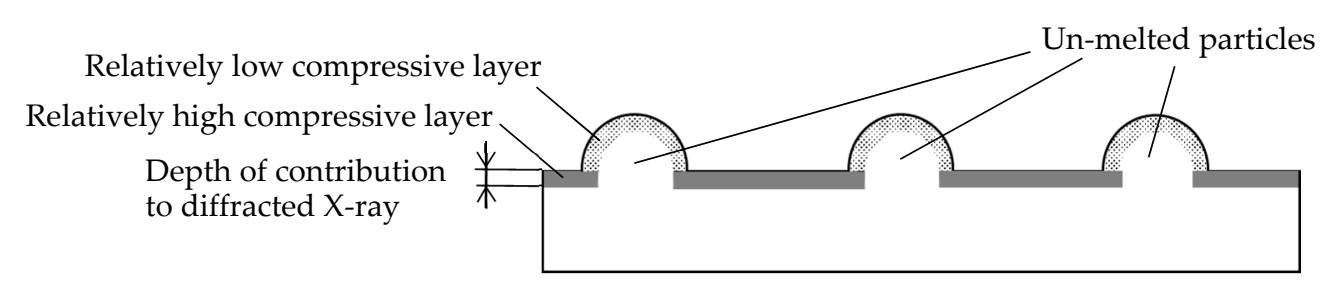

Figure A2. Schematic diagram of X-ray diffraction, considering the surface roughness and depth of the contribution to the diffracted $X$-ray. 


\section{Appendix B}

In order to reveal the cracks that existed before the fatigue test, Figure A3 shows the aspect of the surface of the as-built specimens manufactured by DMLS and EBM. The white arrows in Figure A3 indicate a typical sharp valley. As the aspects were observed by SEM at a higher magnification, cracks or defects were observed at the bottom of the sharp valley.
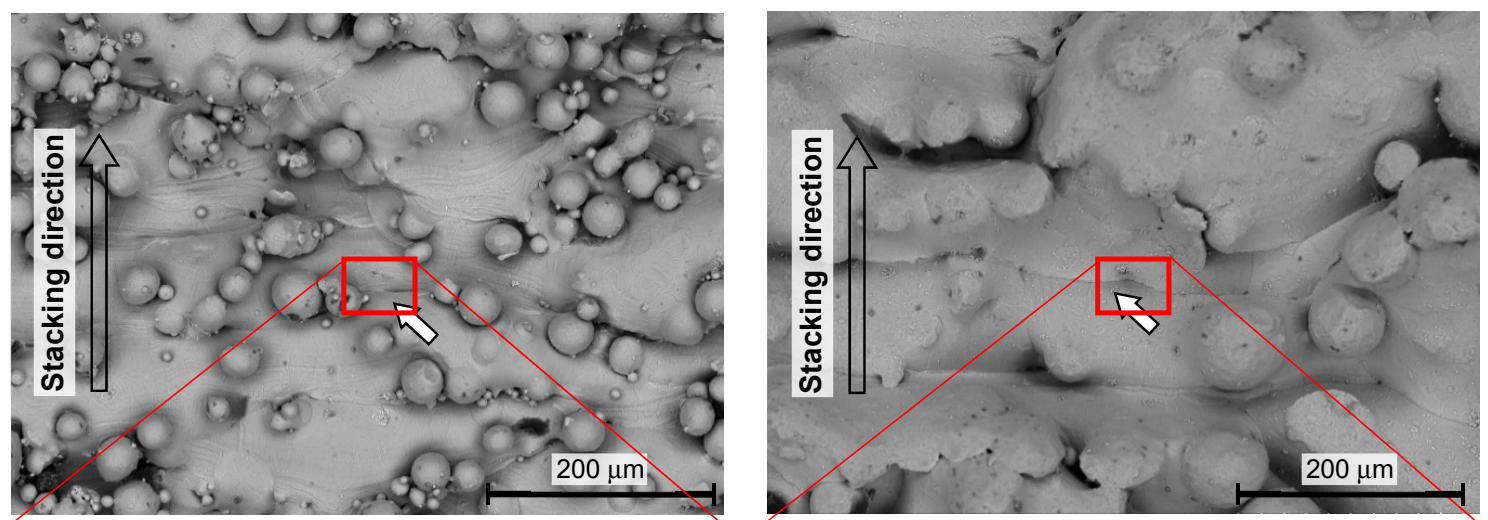

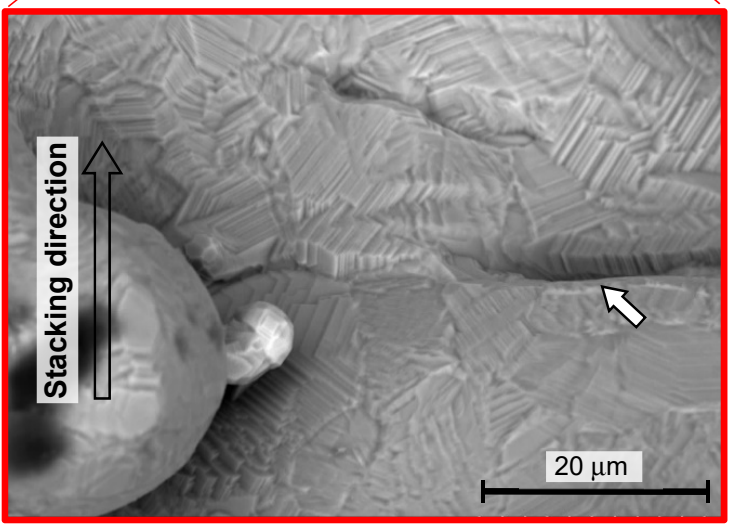

(a) DMLS

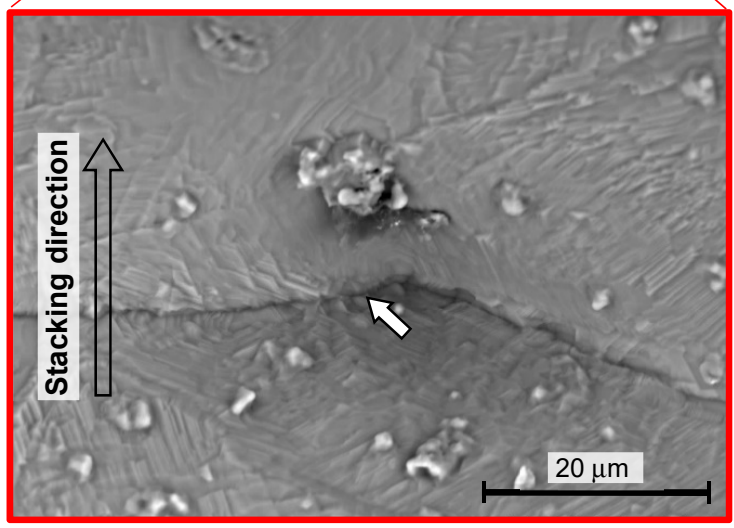

(b) EBM

Figure A3. Aspects of the surface of the as-built specimen, before the fatigue test.

\section{References}

1. Sidambe, A.T. Biocompatibility of advanced manufactured titanium implants-a review. Materials 2014, 7, 8168-8188. [CrossRef]

2. Zhang, L.C.; Chen, L.Y. A review on biomedical titanium alloys: Recent progress and prospect. Adv. Eng. Mater. 2019, 21, 29. [CrossRef]

3. Yavari, S.A.; Wauthle, R.; van der Stok, J.; Riemslag, A.C.; Janssen, M.; Mulier, M.; Kruth, J.P.; Schrooten, J.; Weinans, H.; Zadpoor, A.A. Fatigue behavior of porous biomaterials manufactured using selective laser melting. Mater. Sci. Eng. C Mater. Biol. Appl. 2013, 33, 4849-4858. [CrossRef]

4. Hollander, D.A.; von Walter, M.; Wirtz, T.; Sellei, R.; Schmidt-Rohlfing, B.; Paar, O.; Erli, H.J. Structural, mechanical and in vitro characterization of individually structured Ti6Al4V produced by direct laser forming. Biomaterials 2006, 27, 955-963. [CrossRef]

5. Edwards, P.; O'Conner, A.; Ramulu, M. Electron beam additive manufacturing of titanium components: Properties and performance. J. Manuf. Sci. Eng. Trans. ASME 2013, 135, 1-7. [CrossRef]

6. Edwards, P.; Ramulu, M. Fatigue performance evaluation of selective laser melted Ti6Al4V. Mater. Sci. Eng. A Struct. Mater. Prop. Microstruct. Process. 2014, 598, 327-337. [CrossRef]

7. Uhlmann, E.; Kersting, R.; Klein, T.B.; Cruz, M.F.; Borille, A.V. Additive Manufacturing of Titanium Alloy for Aircraft Components. In Proceedings of the MIC 2015-15th Machining Innovations Conference for Aerospace Industry, Garbsen, Germany, 18-19 November 2015; Denkena, B., Ed.; Elsevier: Amsterdam, The Netherlands, 2015; pp. 55-60. 
8. Li, P.; Warner, D.H.; Fatemi, A.; Phan, N. Critical assessment of the fatigue performance of additively manufactured Ti6Al4V and perspective for future research. Int. J. Fatigue 2016, 85, 130-143. [CrossRef]

9. Fatemi, A.; Molaei, R.; Sharifimehr, S.; Phan, N.; Shamsaei, N. Multiaxial fatigue behavior of wrought and additive manufactured Ti6Al4V including surface finish effect. Int. J. Fatigue 2017, 100, 347-366. [CrossRef]

10. Molaei, R.; Fatemi, A.; Sanaei, N.; Pegues, J.; Shamsaei, N.; Shao, S.; Li, P.; Warner, D.H.; Phan, N. Fatigue of additive manufactured Ti6Al4V, part II: The relationship between microstructure, material cyclic properties, and component performance. Int. J. Fatigue 2020, 132, 19. [CrossRef]

11. Tong, J.; Bowen, C.R.; Persson, J.; Plummer, A. Mechanical properties of titanium-based Ti6Al4V alloys manufactured by powder bed additive manufacture. Mater. Sci. Technol. 2017, 33, 138-148. [CrossRef]

12. Pegues, J.W.; Shao, S.; Shamsaei, N.; Sanaei, N.; Fatemi, A.; Warner, D.H.; Li, P.; Phan, N. Fatigue of additive manufactured Ti6Al4V, part I: The effects of powder feedstock, manufacturing, and post-process conditions on the resulting microstructure and defects. Int. J. Fatigue 2020, 132, 18. [CrossRef]

13. Soyama, H.; Okura, Y. The use of various peening methods to improve the fatigue strength of titanium alloy Ti6Al4V manufactured by electron beam melting. AIMS Mater. Sci. 2018, 5, 1000-1015. [CrossRef]

14. Guo, W.; Sun, R.J.; Song, B.W.; Zhu, Y.; Li, F.; Che, Z.G.; Li, B.; Guo, C.; Liu, L.; Peng, P. Laser shock peening of laser additive manufactured Ti6Al4V titanium alloy. Surf. Coat. Technol. 2018, 349, 503-510. [CrossRef]

15. Soyama, H.; Sanders, D. Use of an abrasive water cavitating jet and peening process to improve the fatigue strength of titanium alloy $6 \mathrm{al}-4 \mathrm{v}$ manufactured by the electron beam powder bed melting (ebpb) additive manufacturing method. JOM 2019, 71, 4311-4318. [CrossRef]

16. Martina, F.; Roy, M.J.; Szost, B.A.; Terzi, S.; Colegrove, P.A.; Williams, S.W.; Withers, P.J.; Meyer, J.; Hofmann, M. Residual stress of as-deposited and rolled wire plus arc additive manufacturing Ti6Al4V components. Mater. Sci. Technol. 2016, 32, 1439-1448. [CrossRef]

17. Oliveira, J.P.; Schell, N.; Zhou, N.; Wood, L.; Benafan, O. Laser welding of precipitation strengthened Ni-rich NiTiHf high temperature shape memory alloys: Microstructure and mechanical properties. Mater. Des. 2019, 162, 229-234. [CrossRef]

18. Oliveira, J.P.; Santos, T.G.; Miranda, R.M. Revisiting fundamental welding concepts to improve additive manufacturing: From theory to practice. Prog. Mater. Sci. 2020, 107, 43. [CrossRef]

19. Carpenter, K.; Tabei, A. On residual stress development, prevention, and compensation in metal additive manufacturing. Materials 2020, 13, 255. [CrossRef]

20. Zadpoor, A.A. Frontiers of additively manufactured metallic materials. Materials 2018, 11, 1566. [CrossRef]

21. Chastand, V.; Quaegebeur, P.; Maia, W.; Charkaluk, E. Comparative study of fatigue properties of Ti6Al4V specimens built by electron beam melting (EBM) and selective laser melting (SLM). Mater. Charact. 2018, 143, 76-81. [CrossRef]

22. Leuders, S.; Thone, M.; Riemer, A.; Niendorf, T.; Troster, T.; Richard, H.A.; Maier, H.J. On the mechanical behaviour of titanium alloy TiAl6V4 manufactured by selective laser melting: Fatigue resistance and crack growth performance. Int. J. Fatigue 2013, 48, 300-307. [CrossRef]

23. Leuders, S.; Lieneke, T.; Lammers, S.; Troster, T.; Niendorf, T. On the fatigue properties of metals manufactured by selective laser melting-The role of ductility. J. Mater. Res. 2014, 29, 1911-1919. [CrossRef]

24. Mower, T.M.; Long, M.J. Mechanical behavior of additive manufactured, powder-bed laser-fused materials. Mater. Sci. Eng. A Struct. Mater. Prop. Microstruct. Process. 2016, 651, 198-213. [CrossRef]

25. Kasperovich, G.; Hausmann, J. Improvement of fatigue resistance and ductility of TiAl6V4 processed by selective laser melting. J. Mater. Process. Technol. 2015, 220, 202-214. [CrossRef]

26. Ahmadi, S.M.; Kumar, R.; Borisov, E.V.; Petrov, R.; Leeflang, S.; Li, Y.; Tumer, N.; Huizenga, R.; Ayas, C.; Zadpoor, A.A.; et al. From microstructural design to surface engineering: A tailored approach for improving fatigue life of additively manufactured meta-biomaterials. Acta Biomater. 2019, 83, 153-166. [CrossRef]

27. Chern, A.H.; Nandwana, P.; Yuan, T.; Kirka, M.M.; Dehoff, R.R.; Liaw, P.K.; Duty, C.E. A review on the fatigue behavior of Ti6Al4V fabricated by electron beam melting additive manufacturing. Int. J. Fatigue 2019, 119, 173-184. [CrossRef]

28. Seifi, M.; Salem, A.; Satko, D.; Shaffer, J.; Lewandowski, J.J. Defect distribution and microstructure heterogeneity effects on fracture resistance and fatigue behavior of ebm Ti6Al4V. Int. J. Fatigue 2017, 94, 263-287. [CrossRef] 
29. Gunther, J.; Leuders, S.; Koppa, P.; Troster, T.; Henkel, S.; Biermann, H.; Niendorf, T. On the effect of internal channels and surface roughness on the high-cycle fatigue performance of Ti6Al4V processed by slm. Mater. Des. 2018, 143, 1-11. [CrossRef]

30. Wang, P.; Sin, W.J.; Nai, M.L.S.; Wei, J. Effects of processing parameters on surface roughness of additive manufactured Ti6Al4V via electron beam melting. Materials 2017, 10, 11.

31. Kahlin, M.; Ansell, H.; Moverare, J.J. Fatigue behaviour of notched additive manufactured Ti6Al4V with as-built surfaces. Int. J. Fatigue 2017, 101, 51-60. [CrossRef]

32. Van Hooreweder, B.; Apers, Y.; Lietaert, K.; Kruth, J.P. Improving the fatigue performance of porous metallic biomaterials produced by selective laser melting. Acta Biomater. 2017, 47, 193-202. [CrossRef] [PubMed]

33. Shui, X.L.; Yamanaka, K.; Mori, M.; Nagata, Y.; Kurita, K.; Chiba, A. Effects of post-processing on cyclic fatigue response of a titanium alloy additively manufactured by electron beam melting. Mater. Sci. Eng. A Struct. Mater. Prop. Microstruct. Process. 2017, 680, 239-248. [CrossRef]

34. Greitemeier, D.; Palm, F.; Syassen, F.; Melz, T. Fatigue performance of additive manufactured TiAl6V4 using electron and laser beam melting. Int. J. Fatigue 2017, 94, 211-217. [CrossRef]

35. Persenot, T.; Burr, A.; Plancher, E.; Buffiere, J.Y.; Dendievel, R.; Martin, G. Effect of ultrasonic shot peening on the surface defects of thin struts built by electron beam melting: Consequences on fatigue resistance. Addit. Manuf. 2019, 28, 821-830. [CrossRef]

36. Sun, Y.Y.; Lu, S.L.; Gulizia, S.; Oh, C.H.; Fraser, D.; Leary, M.; Qian, M. Fatigue performance of additively manufactured Ti6Al4V: Surface condition vs. Internal defects. JOM 2020, 72, 1022-1030. [CrossRef]

37. Wang, X.J.; Xu, S.Q.; Zhou, S.W.; Xu, W.; Leary, M.; Choong, P.; Qian, M.; Brandt, M.; Xie, Y.M. Topological design and additive manufacturing of porous metals for bone scaffolds and orthopaedic implants: A review. Biomaterials 2016, 83, 127-141. [CrossRef]

38. Hinderdael, M.; Strantza, M.; De Baere, D.; Devesse, W.; De Graeve, I.; Terryn, H.; Guillaume, P. Fatigue performance of Ti6Al4V additively manufactured specimens with integrated capillaries of an embedded structural health monitoring system. Materials 2017, 10, 993. [CrossRef]

39. Chan, K.S.; Koike, M.; Mason, R.L.; Okabe, T. Fatigue life of titanium alloys fabricated by additive layer manufacturing techniques for dental implants. Metall. Mater. Trans. A Phys. Metall. Mater. Sci. 2013, 44, 1010-1022. [CrossRef]

40. Kitagawa, H.; Takahashi, S. Applicability of Fracture Mechanics to Very Small Cracks ot the Cracks in the Early Stage. In Proceedings of the 2nd International Conference on Mechanical Behavior of Materials, Boston, MA, USA, 16-20 August 1976; pp. 627-631.

41. Elhaddad, M.H.; Topper, T.H.; Smith, K.N. Prediction of non propagating cracks. Eng. Fract. Mech. 1979, 11, 573-584. [CrossRef]

42. Murakami, Y.; Endo, M. Effects of defects, inclusions and inhomogeneities on fatigue-strength. Int. J. Fatigue 1994, 16, 163-182. [CrossRef]

43. Wycisk, E.; Solbach, A.; Siddique, S.; Herzog, D.; Walther, F.; Emmelmann, C. Effects of Defects in Laser Additive Manufactured Ti6Al4V on Fatigue Properties. In Proceedings of the 8th International Conference on Laser Assisted Net Shape Engineering, Furth, Germany, 8-11 September 2014; Schmidt, M., Vollertsen, F., Merklein, M., Eds.; Elsevier: Amsterdam, The Netherlands, 2014; pp. 371-378.

44. Beretta, S.; Romano, S. A comparison of fatigue strength sensitivity to defects for materials manufactured by AM or traditional processes. Int. J. Fatigue 2017, 94, 178-191. [CrossRef]

45. Greitemeier, D.; Donne, C.D.; Syassen, F.; Eufinger, J.; Melz, T. Effect of surface roughness on fatigue performance of additive manufactured Ti6Al4V. Mater. Sci. Technol. 2016, 32, 629-634. [CrossRef]

46. Benedetti, M.; Torresani, E.; Leoni, M.; Fontanari, V.; Bandini, M.; Pederzolli, C.; Potrich, C. The effect of post-sintering treatments on the fatigue and biological behavior of Ti6Al4V eli parts made by selective laser melting. J. Mech. Behav. Biomed. Mater. 2017, 71, 295-306. [CrossRef] [PubMed]

47. Bagehorn, S.; Wehr, J.; Maier, H.J. Application of mechanical surface finishing processes for roughness reduction and fatigue improvement of additively manufactured Ti6Al4V parts. Int. J. Fatigue 2017, 102, 135-142. [CrossRef]

48. Urlea, V.; Brailovski, V. Electropolishing and electropolishing-related allowances for powder bed selectively laser-melted Ti6Al4V alloy components. J. Mater. Process. Technol. 2017, 242, 1-11. [CrossRef] 
49. Denti, L.; Bassoli, E.; Gatto, A.; Santecchia, E.; Mengucci, P. Fatigue life and microstructure of additive manufactured Ti6Al4V after different finishing processes. Mater. Sci. Eng. A Struct. Mater. Prop. Microstruct. Process. 2019, 755, 1-9. [CrossRef]

50. Boschetto, A.; Bottini, L.; Veniali, F. Surface roughness and radiusing of Ti6Al4V selective laser melting-manufactured parts conditioned by barrel finishing. Int. J. Adv. Manuf. Technol. 2018, 94, 2773-2790. [CrossRef]

51. Witkin, D.B.; Patel, D.N.; Helvajian, H.; Steffeney, L.; Diaz, A. Surface treatment of powder-bed fusion additive manufactured metals for improved fatigue life. J. Mater. Eng. Perform. 2019, 28, 681-692. [CrossRef]

52. Nagalingam, A.P.; Yuvaraj, H.K.; Yeo, S.H. Synergistic effects in hydrodynamic cavitation abrasive finishing for internal surface-finish enhancement of additive-manufactured components. Addit. Manuf. 2020, 33, 101110. [CrossRef]

53. Rosa, B.; Mognol, P.; Hascoet, J.Y. Laser polishing of additive laser manufacturing surfaces. J. Laser Appl. 2015, 27, 7. [CrossRef]

54. Ma, C.P.; Guan, Y.C.; Zhou, W. Laser polishing of additive manufactured Ti alloys. Opt. Lasers Eng. 2017, 93, 171-177. [CrossRef]

55. Nicoletto, G.; Konecna, R.; Frkan, M.; Riva, E. Surface roughness and directional fatigue behavior of as-built EBM and DMLS Ti6Al4V. Int. J. Fatigue 2018, 116, 140-148. [CrossRef]

56. Zhao, X.L.; Li, S.J.; Zhang, M.; Liu, Y.D.; Sercombe, T.B.; Wang, S.G.; Hao, Y.L.; Yang, R.; Murr, L.E. Comparison of the microstructures and mechanical properties of Ti6Al4V fabricated by selective laser melting and electron beam melting. Mater. Des. 2016, 95, 21-31. [CrossRef]

57. Vayssette, B.; Saintier, N.; Brugger, C.; Elmay, M.; Pessard, E. Surface Roughness of Ti-6A1-4V Parts Obtained by SLM and EBM: Effect on the High Cycle Fatigue Life. In Proceedings of the 7th International Conference on Fatigue Design, Fatigue Design, Senlis, France, 29-30 November 2017; Lefebvre, F., Souquet, P., Eds.; Elsevier: Amsterdam, The Netherlands, 2018; pp. 89-97.

58. Liu, S.Y.; Shin, Y.C. Additive manufacturing of Ti6Al4V alloy: A review. Mater. Des. 2019, 164, 23. [CrossRef]

59. Fousova, M.; Vojtech, D.; Doubrava, K.; Daniel, M.; Lin, C.F. Influence of inherent surface and internal defects on mechanical properties of additively manufactured Ti6Al4V alloy: Comparison between selective laser melting and electron beam melting. Materials 2018, 11, 537. [CrossRef] [PubMed]

60. Gong, H.J.; Rafi, K.; Gu, H.F.; Ram, G.D.J.; Starr, T.; Stucker, B. Influence of defects on mechanical properties of Ti6Al4V components produced by selective laser melting and electron beam melting. Mater. Des. 2015, 86, 545-554. [CrossRef]

61. Rafi, H.K.; Karthik, N.V.; Gong, H.J.; Starr, T.L.; Stucker, B.E. Microstructures and mechanical properties of Ti6Al4V parts fabricated by selective laser melting and electron beam melting. J. Mater. Eng. Perform. 2013, 22, 3872-3883. [CrossRef]

62. Rodriguez, O.L.; Allison, P.G.; Whittington, W.R.; El Kadiri, H.; Rivera, O.G.; Barkey, M.E. Strain rate effect on the tension and compression stress-state asymmetry for electron beam additive manufactured Ti6Al4V. Mater. Sci. Eng. A Struct. Mater. Prop. Microstruct. Process. 2018, 713, 125-133. [CrossRef]

63. Rozumek, D.; Hepner, M. Influence of microstructure on fatigue crack propagation under bending in the alloy Ti6A14V after heat treatment. Materialwiss. Werkstofftech. 2015, 46, 1088-1095. [CrossRef]

64. Rozumek, D.; Hepner, M. Influence of oxygenation time on crack growth in titanium alloy under cyclic bending. Mater. Sci. 2011, 47,89-94. [CrossRef]

65. Sato, M.; Takakuwa, O.; Nakai, M.; Niinomi, M.; Takeo, F.; Soyama, H. Using cavitation peening to improve the fatigue life of titanium alloy Ti6Al4V manufactured by electron beam melting. Mater. Sci. Appl. 2016, 7, 181-191.

66. Kahlin, M.; Ansell, H.; Basu, D.; Kerwin, A.; Newton, L.; Smith, B.; Moverare, J.J. Improved fatigue strength of additively manufactured Ti6Al4V by surface post-processing. Int. J. Fatigue 2020, 134, 12. [CrossRef]

67. Salvati, E.; Lunt, A.J.G.; Ying, S.; Sui, T.; Zhang, H.J.; Heason, C.; Baxter, G.; Korsunsky, A.M. Eigenstrain reconstruction of residual strains in an additively manufactured and shot peened nickel superalloy compressor blade. Comput. Meth. Appl. Mech. Eng. 2017, 320, 335-351. [CrossRef]

68. Zhang, M.X.; Liu, C.M.; Shi, X.Z.; Chen, X.P.; Chen, C.; Zuo, J.H.; Lu, J.P.; Ma, S.Y. Residual stress, defects and grain morphology of Ti6Al4V alloy produced by ultrasonic impact treatment assisted selective laser melting. Appl. Sci. 2016, 6, 7. [CrossRef] 
69. Sasoh, A.; Watanabe, K.; Sano, Y.; Mukai, N. Behavior of bubbles induced by the interaction of a laser pulse with a metal plate in water. Appl. Phys. A 2005, 80, 1497-1500. [CrossRef]

70. Soyama, H. Cavitation peening: A review. Metals 2020, 10, 270. [CrossRef]

71. Sano, Y. Quarter century development of laser peening without coating. Metals 2020, 10, 152. [CrossRef]

72. Brennen, C.E. Cavitation and Bubble Dynamics; Oxford University Press: New York, NY, USA, 1995.

73. Soyama, H. Key factors and applications of cavitation peening. Inter. J. Peen. Sci. Technol. 2017, 1, 3-60.

74. Kanou, S.; Takakuwa, O.; Mannava, S.R.; Qian, D.; Vasudevan, V.K.; Soyama, H. Effect of the impact energy of various peening techniques on the induced plastic deformation region. J. Mater. Process. Technol. 2012, 212, 1998-2006. [CrossRef]

75. Soyama, H. Comparison between the improvements made to the fatigue strength of stainless steel by cavitation peening, water jet peening, shot peening and laser peening. J. Mater. Process. Technol. 2019, 269, 65-78. [CrossRef]

76. Soyama, H. Comparison between shot peening, cavitation peening and laser peening by observation of crack initiation and crack growth in stainless steel. Metals 2020, 10, 63. [CrossRef]

77. Soyama, H.; Takeo, F. Comparison between cavitation peening and shot peening for extending the fatigue life of a duralumin plate with a hole. J. Mater. Process. Technol. 2016, 227, 80-87. [CrossRef]

78. Takakuwa, O.; Soyama, H. The effect of scanning pitch of nozzle for a cavitating jet during overlapping peening treatment. Surf. Coatings Technol. 2012, 206, 4756-4762. [CrossRef]

79. Soyama, H. Enhancing the aggressive intensity of a cavitating jet by introducing a cavitator and a guide pipe. J. Fluid Sci. Technol. 2014, 9, 1-12, paper No. 13-00238. [CrossRef]

80. Soyama, H. Enhancing the aggressive intensity of a cavitating jet by means of the nozzle outlet geometry. $J$. Fluids Eng. 2011, 133, 1-11, paper No. 101301. [CrossRef]

81. Philipp, A.; Lauterborn, W. Cavitation erosion by single laser-produced bubbles. J. Fluid Mech. 1998, 361, 75-116. [CrossRef]

82. Soyama, H. Introduction of Compressive Residual Stress into Alloy Tool Steel by Submerged Laser Peening Utilizing Laser Cavitation Impact. In Proceedings of the 9th International Conference on Leading Edge Manufacturing in 21st Century, LEM 2017, Hiroshima City, Japan, 13-17 November 2017. Article Number 010 .

83. Naito, A.; Takakuwa, O.; Soyama, H. Development of peening technique using recirculating shot accelerated by water jet. Mater. Sci. Technol. 2012, 28, 234-239. [CrossRef]

84. He, B.B. Two-Dimensional X-Ray Diffraction; John Wiley \& Sons, Inc.: Hoboken, NJ, USA, 2009; pp. $249-328$.

85. Soyama, H. Comparison of various XRD methods on evaluation of residual stress introduced by submerged laser peening. Metal Finish. News 2018, 19, 54-57.

86. Takakuwa, O; Soyama, H. Optimizing the conditions for residual stress measurement using a two-dimensional XRD method with specimen oscillation. Adv. Mater. Phys. Chem. 2013, 3, 8-18. [CrossRef]

87. Little, R.E. Estimating the median fatigue limit for very small up-and-down quantal response tests and for S-N data with runouts. ASTM STP 1972, 511, $29-42$.

88. Data Sheet on Giga-Cycle Fatigue Properties of Ti6Al4V (900 MPa Class) Titanium Alloy; NIMS Fatigue Data Sheet No. 92; National Institute for Materials Science: Tsukuba, Japan, 2004; pp. 1-12.

89. Taylor, J.R. An Introduction to Error Analysis: The Study of Uncertainties in Physical Measurements; University Science Books: Mill Valley, CA, USA, 1982.

(C) 2020 by the authors. Licensee MDPI, Basel, Switzerland. This article is an open access article distributed under the terms and conditions of the Creative Commons Attribution (CC BY) license (http://creativecommons.org/licenses/by/4.0/). 